
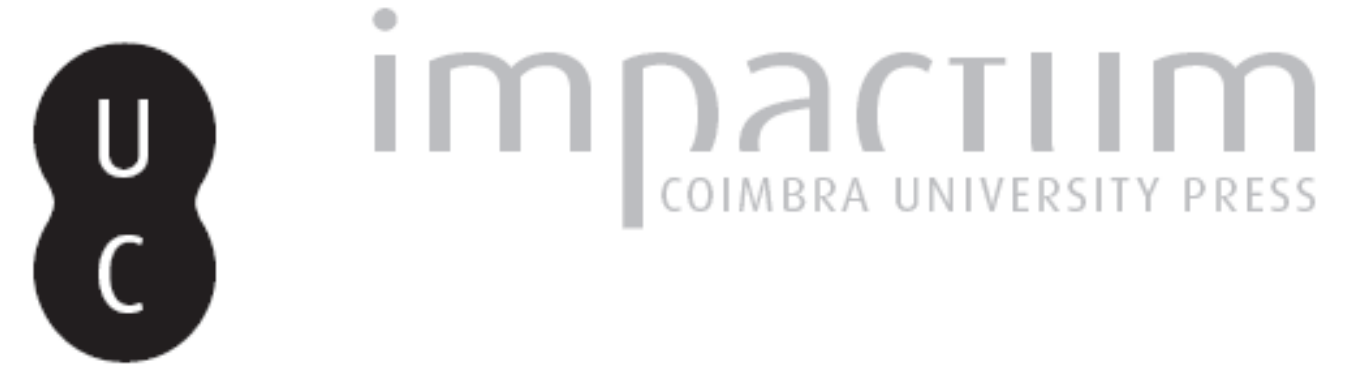

\title{
Movimentos de vertente, análise de risco e ordenamento do território: o exemplo recente do fluxo deslizante de Armamar (Douro Vinhateiro, Portugal)
}

Autor(es): $\quad$ Santos, J. Gomes

Publicado por: Associação Portuguesa de Riscos, Prevenção e Segurança

URL persistente:

URI:http://hdl.handle.net/10316.2/40053

DOI:

DOI:https://doi.org/10.14195/1647-7723_11_3

Accessed : $\quad$ 26-Apr-2023 11:51:48

A navegação consulta e descarregamento dos títulos inseridos nas Bibliotecas Digitais UC Digitalis, UC Pombalina e UC Impactum, pressupõem a aceitação plena e sem reservas dos Termos e Condições de Uso destas Bibliotecas Digitais, disponíveis em https://digitalis.uc.pt/pt-pt/termos.

Conforme exposto nos referidos Termos e Condições de Uso, o descarregamento de títulos de acesso restrito requer uma licença válida de autorização devendo o utilizador aceder ao(s) documento(s) a partir de um endereço de IP da instituição detentora da supramencionada licença.

Ao utilizador é apenas permitido o descarregamento para uso pessoal, pelo que o emprego do(s) título(s) descarregado(s) para outro fim, designadamente comercial, carece de autorização do respetivo autor ou editor da obra.

Na medida em que todas as obras da UC Digitalis se encontram protegidas pelo Código do Direito de Autor e Direitos Conexos e demais legislação aplicável, toda a cópia, parcial ou total, deste documento, nos casos em que é legalmente admitida, deverá conter ou fazer-se acompanhar por este aviso.

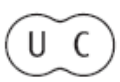




\section{Movimentos de vertente, análise de risco e ordenamento do território; o exemplo recente do fluxo deslizante de Armamar (Douro Vinhateiro, Portugal)}

\section{J. Gomes Santos*}

Resumo:

No dia 3 de Janeiro de 2003, a Estrada Nacional 222 que, pela margem esquerda do Douro, liga Peso da Régua à localidade de Pinhão, foi destruída ao $\mathrm{Km} 37 \pm 300 \mathrm{~m}$, numa extensão de cerca de 60 metros, em toda a sua largura, em consequência da movimentação newtoniana de materiais detríticos que estruturam os socalcos das vertentes adaptadas ao cultivo da vinha. Sem consequências ao nível da perda de vidas humanas, a contingência do desastre viria, contudo, a materializar-se pela destruição da referida estrada e de uma área significativa de vinha e da própria vertente, bem como pelos elevados custos a que obrigaram, por um lado, a reconstrução da estrada e, por outro lado, a correcção e estabilização da vertente. Os efeitos decorrentes deste desastre "natural" destacam-se também pelos elevados transtornos que impuseram à dinâmica sócioeconómica da região. Tratando-se de acidentes que geralmente são induzidos pela intervenção humana na morfodinâmica das vertentes, este é apenas mais um exemplo, o mais recente, de instabilidade associada às vertentes do Douro Vinhateiro, pelo que a tomada de consciência para a gravidade do problema constitui, cada vez mais, um importante requisito para o correcto ordenamento do espaço e para gestão dos recursos, em respeito para com as leis da Física... que são também as da Natureza.

Palavras-Chave:

Movimento de vertente, Fluxo deslizante, Vulnerabilidade, Análise de risco, Ordenamento do Território.

\section{Resumé:}

Le 3 janvier de 2003, la route national 222, entre Régua et Pinhão a été complètement détruite sur $60 \mathrm{~m}$, comme résultat d'un mouvement de versant avec les matériaux déplacés des "socalcos" tipiques de la Région du Douro, région où le vin de Porto est produit. Ce mouvement n'a pas fait des morts, mais, au delà de la détrution de la route, il a aussi détruit des vignobles et une partie significative du versant. Tout ça veut dire beaucoup d'argent. II s'agit d'accidents en général induits par l'homme sur la morphodynamique des versants. C'est pourquoi il faut faire attention à la gravité du problème et en prendre compte qu'il est très important pour l'aménagement de l'espace et pour la gestion des ressources dans le respect avec les lois de la Physique qui sont aussi des lois de la Nature.

Mots clés:

Mouvement de versant, Glissement, Vulnerabilité, Analyse du risque, Aménagement du territoire.

\section{Abstract:}

A very important Portuguese northern road - E.N. 222 - was destroyed on January the $3^{\text {rd }}, 60 \mathrm{~m}$ length, on all it's width, as the result of a newtonian debris movement of the material that structures the "socalcos", it means, the slopes of the Douro Wine Growing Region, between Peso da Régua and Pinhão. This landslide did not produce injuries, or even deaths, but has destroyed a significant part of the road, a very large area of vineyard and the slope itself, beyond the big costs involved in the road and slope reconstruction and stabilization. The social and economics main derangements were evident for all, and they were a consequence of a very long alternative way that people had to go through for reaching any of those two villages. In this region, landslides, concretely, flow slides, are human induced phenomena and this one is just an example more, the recent one, that calls upon the consciousness for the magnitude of this kind of problems. This behaviour constitutes a very important attribute in terms of an efficient land use and planning, and resources management that respects Physics, so... Nature' s laws.

Key-words:

Landslide, Flow slide, Vulnerability, Risk analysis, Land planning.

\section{Introdução}

Desde o Outono-Inverno de 2000-2001 que a problemática da dinâmica de vertentes no Douro Vinhateiro tem chamado particularmente a nossa atenção. Este espaço físico integra a área onde estamos a desenvolver estudos mais amplos com vista a aprofundar significativamente o conhecimento geomorfológico desta área do território de Portugal continental. Foi esta mesma problemática que nos despertou para o carácter, de algum modo, singular, da morfodinâmica das vertentes vinhateiras talhadas em litologia metassedimentar. A atenção que temos vindo a dedicar a esta questão, permite enquadrá-la

* Instituto de Estudos Geográficos e Centro de Estudos Geográficos. Faculdade de Letras da Universidade de Coimbra. no âmbito mais amplo da dinâmica (geo) sistémica. Por definição, o Geossistema é aberto, complexo e indivisível do ponto de vista do funcionamento orgânico. O espaço vinhateiro está muito bem definido, em termos de fronteiras físicas mas também paisagísticas que the conferem uma identidade morfostrutural e morfodinâmica singulares no conjunto do território nacional.

Associadas ao contexto morfostrutural que disponibiliza autênticas rampas que induzem a movimentação de material detrítico, as características dos mecanismos de ruptura geralmente envolvidos traduzem-se pela elevada capacidade de destruição associada a esta categoria de mecanismos de vertente. Em situações extremas, podemos estar a falar de mecanismos que culminam em contextos de "crise" no sentido atribuído por Rebelo (1995) envolvendo, com frequência, a 
perda de algumas vidas humanas e avultados prejuízos materiais. Da perspectiva financeira à social, da ecológica à ambiental, da psicológica, vivencial e individual, à histeria e fobia colectivas, inequivocamente espelhadas nos dados recolhidos em inquéritos realizados às populações, todas elas constituem "traços-tipo de contextos de vida" caracterizados por forte preocupação e sentimento de insegurança também espelhados no rosto das populações. Relacionada com os riscos (ditos) "naturais", esta categoria de problemas-que representa uma ameaça mais preocupante do que as próprias cheias cíclicas do Douro ou mesmo do que os incêndios florestais ${ }^{(1)}$ - tem vindo a motivar interesse particular por parte de várias entidades ligadas directamente aos processos de decisão no. vasto âmbito do Ordenamento do Território, designadamente a extinta DRAÖT-Norte.

A procura de modelos interpretativos que permitam uma aproximação a esta problemática, tem vindo a materializar-se pela construção de diversos documentos que deverão ser sempre considerados apenas como abordagens pessoais, e em permanente reconstrução, tal é a dimensão da complexidade do sistema em causa que, em boa medida, resulta da grande diversidade de variáveis intervenientes e das dificuldades impostas pela sua difusa interacção (interna) e destas com aparelhos sistémicos ainda mais complexos e passíveis de análise multi-escalar relacionados, por exiemplo, com o clima ou com a própria organização social de um território. A dimensão orgânica é (porventura?) a verdadeira essência da dinâmica geossistémica. O amplo leque de possíveis ensaios de análise combinatória define um campo aberto a possibilidades de interacção entre as diversas variáveis, pelo que o próprio cálculo probabilístico, não tenhamos dúvidas, terá sempre grandes dificuldades em aprisionar - com rigor - um perfil-tipo para a identificação de "áreas em risco" o que significa que, em simultâneo, o "quando" e o "onde" não estão ainda ao alcance da Ciência, pelo menos, em termos absolutos. Tal grau de desordem remete-nos para o âmbito incontornável de um modelo cujo comportamento evidencia elevado grau de entropia, com padrão quase caótico, mas que teimosa e repetidamente insistimos em tentar sistematizar com recurso a ensaios de individualização de comportamentos, sequencialização de etapas e parametrização de contributos das diversas variáveis envolvidas (pelo menos das que são conhecidas) com vista à proposta de modelos que mais não são do que meras tentativas de aproximação à realidade.

(1) De acordo com os dados de um inquérito local efectuado em Março de 2001 , cerca de dois meses após a crise decorrente dos movimentos de Ariz e de Alvaçōes do Corgo.

\section{Enquadramento terminológico e conceptual}

A violência dos fenómenos e a magnitude dos impactes produzidos pelo tipo de mecanismos predominante nos movimentos de vertente inventariados, permitem-nos avançar com a ideia de que esta área do Norte de Portugal constitui um espaço com elevada susceptibilidade à ocorrência de mecanismos específicos que legitimam a designação de "país dos flow slides ${ }^{(2) "}$.

Constituindo uma sub-classe dos movimentos do tipo debris flow (fluxos ou escoadas de detritos) esta categoria muito específica de movimentos de vertente passou a ser frequentemente aplicada a contextos que envolvem meios anisotrópicos onde se confrontam materiais geralmente soltos e pouco compactados, em geral, de origem antrópica ${ }^{(3)}$, suprajacentes a substratos rochososcoerentes, relativamente impermeáveis. O plano de descontinuidade que promove o contacto entre ambas as categorias litológicas, em condições de circulação hídrica sub-superficial favorece particularmente a instabilização do material detrítico que pode culminar na sua movimentação total ou parcial. De acordo com HUTCHINSON (1988), referido por IBSEN, BRUNSDEN, BROMHEAD \& COLLISON, na obra de DIKAU et al., 1996), um movimento desta natureza caracteriza-se pelo súbito e extenso colapso de material detrítico com textura granular que se desloca de modo muito rápido a extremamente rápidoem consequência de um distúrbio produzido na estabilidade do sistema-vertente. Uma característica essencial reside na existência de material solto, pouco compactado (loose material) ou de estruturas comelevada porosidade. Comoconsequência do distúrbio produzido, por exemplo, pelo aumento - súbito ou gradual - das pressões dos fluidos que ocupam os poros intersticiais, a estrutura colapsa em

(2) Em trabalhos anteriores ((J.G.SANTOS, 2001-2003 e J.G.SANTOS et ai. 2003) utilizámos esta expressão sem a preocupação de encontrar um equivalente terminológico de língua portuguesa. No entanto, pensamos que a frequência com que este tipo de mecanismo se tem vindo a manifestar na área do Douro Vinhateiro, justifica que sejam estes, a sede e o momento oportunos, para propor a utilização formal da expressão "Fluxo deslizante". Justificamos esta opção com o facto de se tratar de um mecanismo que constitui um caso particular dos movimentos classificados como "fluxos", que envolve uma componente de deslizamento planar afectando material detrítico pouco coeso pouco compactado. Este mecanismo foi inicialmente identificado no designado "Movimento de Aberfan"-Gales, (IBSEN, et al., referidos em DIKAU et. al., 1996) e está amplamente referido na literatura da especialidade destacando-se, BRUNSDEN \& PrIOR (1984), para além dos autores referidos no texto. Uma opção alternativa para designar este movimento de vertente poderia consistir em "Deslizamento fluxivo"; no entanto, a sua utilização seria passível de sugerir tratar-se de um mecanismo mais próximo da categoria "deslizamento", o que não corresponde à realidade, conforme anteriormente foi referido.

(3) De acordo com BISHOP (1973) referido por IBSEN, BRUNSDEN, BROMHEAD \& COLLISON, na obra de DIKAU et al. . (1996), apesar de estar frequentemente associado a empilhamentos de material de origem antrópica que constituem grandes aterros ou mesmo pequenos cabeços, este tipo de movimentos pode também ocorrer em materiais detríticos de origem geológica, envolvendo por exemplo, mantos de alteração. 
resultadoda transferência do excesso de carga (pressão) total ou parcialmente, para os sectores da vertente com menor capacidade dissipação que podem corresponder (ou não) aos sectores onde o sistema de forças resistentes é vencido pelo sistema de forças instabilizadoras. É particularmente importante o efeito de "explosão" (air blast) que este tipo de movimentos exerce sobra as infra-estruturas que encontra pela frente, deixando marcas indeléveis do enorme poder de aceleração típico do material em movimento, da elevada quantidade de energia potencialmente envolvida e do consequente potencial de destruição que ambas podem causar.

Os materiais movimentados sob a acção de fluxos deslizantes não só fluidificam muito depressa como solidificam também muito rapidamente o que origina uma fonte potencial de perigo, porventura não menos importante, no sector de acumulação progradante, no lobo frontal do movimento.

Em síntese, trata-se de um sub-tipo particular de fluxo o que dificulta a sua adaptação para a literatura de expressão lusa; se decompusermos a expressão flow slide, somos conduzidos a pensar num mecanismo complexo que envolve a movimentação de materiais por acção de um fluxo (flow) e de um deslizamento (slide); assim, optámos, parajá, por adoptar a expressão

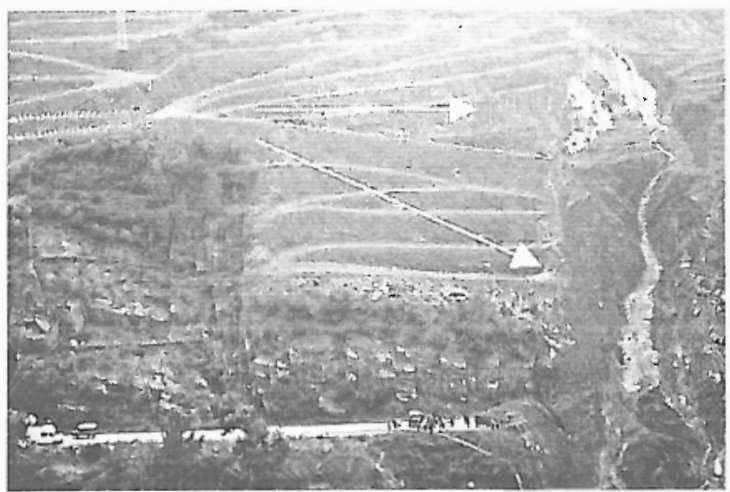

Foto1 - A) Plano de descontinuidade entre a rocha coerente e a cobertura detrítica (Movimento de Armamar, Janeiro de 2003);

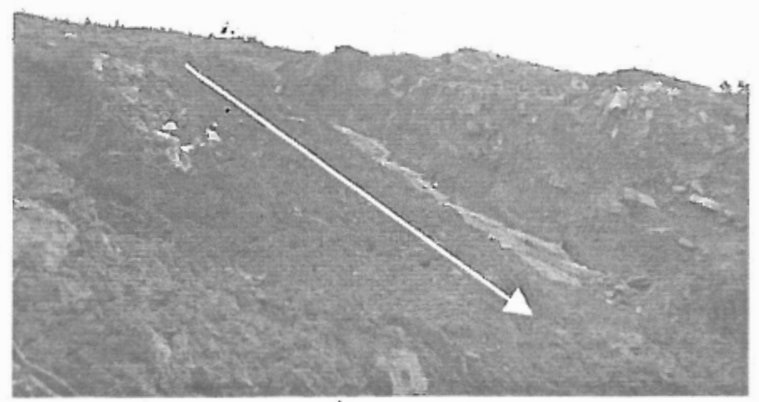

Fotol - B) Idem, pormenor. "fluxo deslizante" em detrimento, por exemplo, de "deslizamento fluxivo", na medida em que, como anteriormente se referiu, se trata, em primeiro lugar, de um movimento que se enquadra na categoria dos fluxas e não dos deslizamentos. No entanto, a descontinuidade ao longo da qual geralmente se produz o movimentoé planar, denunciando o controlo estrutural da instabilização produzida na vertente, num sector que apresenta uma fraca resistência ao corte quando sobre ele é aplicada uma força tangencial cuja intensidade ultrapasse o limiar de esforço tolerável pela vertente (relação forças instabilizadoras/forças resistentes - shear stress/shear strenght). Esta ideia está bem presente na segunda parte da expressão (slide). Ora, os dados recolhidos no terreno e os que entretanto foram tratados e processados, levam-nos a admitir que estamos perante um movimento de vertente que, no essencial, apresenta características semelhantes às que acabam de ser descritas. A descontinuidade planar existe, comprova-se pela observação da foto 1 ( $\mathrm{A}$ e B $)$, tal como havíamos já observado em outros movimentos recentes, como o de Alvações do Corgo, Janeiro de 2001 (foto 2), este critério constitui

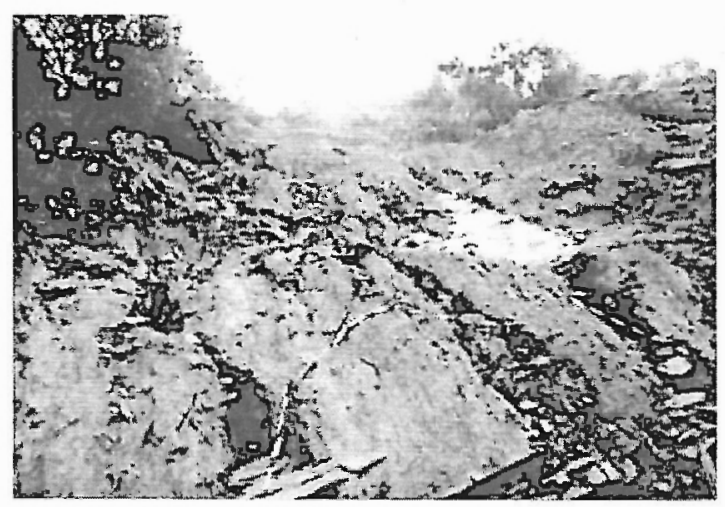

Foto 2 - Plano de descontinuidade entre a rocha coerente e a cobertura detrítica (Movimento de Alvaçōes do Corgo, Janeiro de 2001);

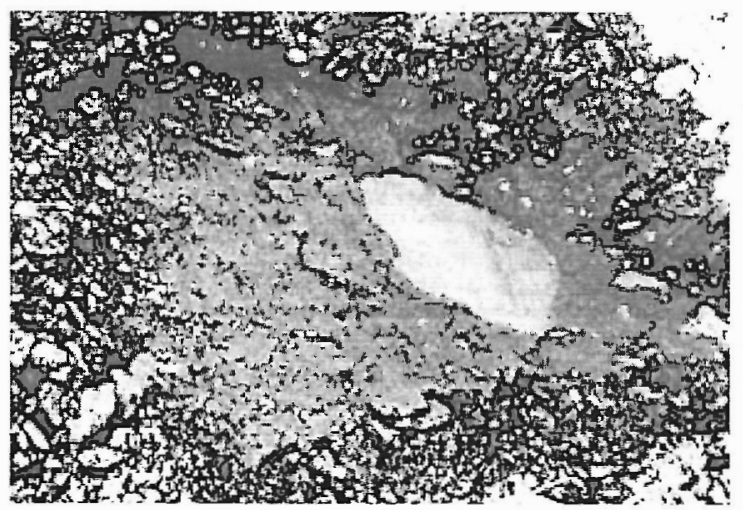

Foto 3 - Aberfan (Reprodução de Bishop, 1973, autorizada pela Geological Society, in Ibsen, Brunsden, Bromhead \& Collison, na obra de Dikau et al., 1996) 
outro argumento para estabelecer um paralelismo morfodinâmico com o caso de Aberfan (foto 3).

Oessencial do movimento complexo de Armamar, que destruiu a E.N. 222 ao $\mathrm{Km} 37 \pm 300$ m ficou, portanto, a dever-se a um mecanismo que não deixa grandes dúvidas relativamente à sua classificação - "Fluxo deslizante".

\section{Enquadramento metodológico no âmbito da Análise Quantitativa do Risco (AQR)}

Temos procurado combinar dados qualitativos e quantitativos, empírica e cientificamente processados, numa análise do "risco" que possibilite a sua aplicabilidade à tomada de decisão, num claro sinal de cooperação entre Ciência, Sociedade e Ordenamento do Território. Este campo nãoé da exclusiva competência do Geógrafo. Dispondo de outra formação científica e sensibilidade, os profissionais com quem trabalha ou possa vir a trabalhar, em franca e aberta interdisciplinaridade, solicitam-lhe, cada vez com maior frequência, saberes e tarefas que lhe imputam a tremenda responsabilidade de, com rigor, informar "quem decide". Neste domínio, pensamos que a cartografia de susceptibilidades e de riscos, desempenha um papel nuclearna tentativa de compreender a localização dos movimentos de vertente e identificar as vertentes mais susceptíveis a este tipo de manifestações de instabilidade. Não temos dúvidas de que estamos perante a "velhinha" mas sempre actual dualidade geográfica da abordagem geossistémica, em que a análise espacial não pode ser independente da dimensão temporal. Recorrendo a uma expressão muito em voga, que define o espectro do "global ao local", estamos no domínio das escalas que mais não é do que o domínio do espaço, logo, do campo de acção privilegiado pelo Geógrafo. As análises de "tempo longo" integradas com as de "tempo curto" recordam a sábia frase de VARNES (1984) que nos recomenda que devemos aprender com as liçôes do passado, associando e, diríamos mais, prevendo, a ocorrência potencial dos movimentos de vertente (susceptibilidade), preferencialmente, em áreas onde já há registos factuais ou em outras cujos contextos, geológico e geomorfológico, são semelhantes.

Associada à complexidade das noções de "vulnerabilidade" dos "elementos em risco" e de "resiliência" do (geo) sistema afectado, a recente ocorrência do movimento de vertente que destruiu a estrada nacional (E.N.) 222 ao $\mathrm{Km} 37$, constitui um excelente exemplo para se entender a volatilidade dos conceitos, a contingência e subjectividade a eles associadas, logo, a grande prudência que se recomenda na sua análise, em particular, quando se trate do estudo do primeiro dos conceitos referidos.
A análise e a avaliação das vulnerabilidades devem englobar, em primeiro lugar, estudos relativos às pessoas teoricamente expostas a uma fonte de perigo potencial. O tipo e o grau de lesão de que podem vir a ser alvos, a averiguação da sua reversibilidade ou irreversibilidade e, subindo na escala de análise da gravidade dos efeitos produzidos, a eventual perda de vidas humanas são os critérios que, sem hesitar, consideramos como prioritários para a hierarquização dos coeficientes de vulnerabilidade aplicados aos diferentes espaços funcionais.

Entendemos, por outro lado, que a lógica da componente económico-social, que nãoéa do Geógrafo mas antes a do Homem Económico ou, mesmo, a do Social, deve ser considerada como menos importante para efeitos de formulação de modelos de avaliação de base quantitativa assentes na atribuição de coeficientes de vulnerabilidade dos diferentes espaços funcionais. Facilmente se constata, que a subjectividade intrínseca ao conceito e à sua análise legitimam várias perspectivas de abordagem e vários modelos, tantas quantas as sensibilidades das pessoas envolvidas. Pensemos nas seguradoras e nos dados que privilegiam para o cálculo dos "coeficientes de risco" dos quais dependem os próprios prémios! Que concluir sobre quem deve estar primeiro? As pessoas ou os danos materiais que possam decorrer de um incêndio, de um deslizamento, de um fluxo de detritos, de uma tempestade tropical ou de um sismo? E que paralelo se pode estabelecer com os critérios utilizados no caso de um acidente rodoviário? Pensemos, ainda, na contingência e na volatilidade intrínsecas ao conceito de "vulnerabilidade" e à sua variabilidade, não só no espaço, como, acima de tudo, no tempo! O recente acidente da E.N. 222, ao Km 37, é um excelente exemplo para que se consiga entender esta questão tanto mais quando a sua análise é confrontada com a queda da ponte de Entre-os-Rios, ali bem perto, também na bacia do Douro. Se, neste caso, houve a lamentar a perda de várias dezenas de vidas humanas, do movimento de vertente de Armamar não resultaram vítimas mortais, mas houve danos materiais significativos. Neste contexto, no caso de Armamar, a vulnerabilidade dos elementos em risco adquire um coeficiente " $X$ ". No entanto, se naquele preciso momento, uma pessoa que circulasse num motociclo tivesse morrido, a vulnerabilidade daquela infra-estrutura, naquela mesma área, já assumia outro valor. Por outro lado, se o mesmo movimento tivesse ocorrido, não às 22 horas, mas, por exemplo, às 18 horas, e nesse preciso momento fosse a passar um autocarro com 50 passageiros, se o mesmo fenómeno fosse fatal para todos eles que valor atribuir à vulnerabilidade daquele espaço? Não teríamos a reedição de "Entre-os-Rios"? Sugerimos, deste modo, uma reflexão comparativa sobre o tempo que os 
media dedicaram a ambas as situações, Entre-os-Rios e Armamar - E.N. 222! A volatilidade desta questão está, assim, justificada e a problemática que encerra tem tradução material e imaterial, em todos os domínios, do social ao económico; no espaço, vai do local ao regional, o que impõe uma correcta articulaçãodas diferentes escalas; no tempo,équase transversal, ou seja, interfere com as medídas de conjuntura (de tempo curto) mas também com as estruturais, geralmente prolongadas (de tempo médio a longo).

$\mathrm{Na}$ área classificada do Douro Vinhateiro são já muitos os exemplos de movimentos de vertente catastróficos que colocaram em causa a própria filosofia e a orientação do Planeamento Urbano e do Ordenamento do Território, alguns dos quais envolveram mesmo a perda de vidas humanas. Por outro lado, as suas consequências põem a descoberto as falhas de colaboraçãoentre técnicos e investigadores. Pensamos, por isso, que a cartografia, concretamente, de susceptibilidades, de vulnerabilidades e de riscos, poderá constituir uma via consistente para o encontro de esforços no sentido de optimizar e operacionalizar a informação disponível para o correcto Ordenamento do Território.

Ao zonamento das áreas mais susceptíveis à ocorrência de determinados tipos de movimentos de vertente (susceptibilidades) deverá seguir-se um processo de análise, avaliação e, finalmente, zonamento das vulnerabilidades dos elementos em risco e, por fim, do cruzamento destas duas categorias de informação deverá resultar um valor (coeficiente) de risco variável em função da fórmula de cálculo ${ }^{(4)}$

(4) São diversas as expressões matemáticas utilizadas por diversos autores numa tentativa de modelizar padrões de comportamento deste tipo de mecanismos com aplicação aos "Riscos naturais". Destacamos algumas das expressões que traduzem as designadas "Equações gerais do Risco (R) ou Coeficiente de risco (Cr)" que conotam a noção de "Risco" com o resultado da combinação algébrica de soma da susceptibilidade $(S)$ com a Vulnerabilidade (V) ou, em outros casos, com o produto destes dois factores (o que levanta alguns problemas quando um deles é "nulo"). $\mathrm{O}$ conceito de "Risco" pode ser traduzido também por uma expressão que acrescente uma função (Logarítmica, Exponencial, Derivada, Integral, etc,) da soma ou do produto daqueles dois factores. Em situações ainda mais complexas, que demonstram bem a dificuldade em encontrar um modelo universal que permita identificar, sem equívocos, o padrão da distribuição espacial dos movimentos de vertente e, ao mesmo tempo, o momento da sua ocorrência, outros autores recorrem ao conceito de resiliência (Rl) de um sistema que consiste na sua capacidade de evoluir no sentido de recuperaro equilîbrio perturbado por um distúrbio desencadeado por um factor (ou conjunto de factores) al heio ao seu normal funcionamento. Porque este conceito depende directamente do conjunto de "Aptidōes, Capacidades e Competências (ACC)" do próprio um sistema, algumas expressôes mais complexas propõem que "Risco" ou o "Coeficiente de risco" possa ser traduzido por uma função do quociente entre a soma algébrica ou o produto de "S" por "V", e a soma algébrica das ACC com a Rl, tal como se apresenta:

1) Risco $(\mathbf{R})=$ Susceptibilidade $(\mathbf{S})+$ Vulnerabilidade (V)];

2) $\operatorname{Risco}(\mathbf{R})=f$ [usceptibilidade $(\mathbf{S})+$ Vulnerabilidade $(\mathbf{V})]$

3) Risco (R)= [Susceptibilidade (S) $x$ Vulnerabilidade (V)];

4) $\operatorname{Risco}(\mathbf{R})=f$ [Susceptibilidade (S) $\times$ Vulnerabilidade (V)];

5) $\operatorname{Risco}(\mathbf{R})=$ Susceptibilidade (S) + Vulnerabilidade (V)]; considerada pelo investigador, expressão que the permite propor o zonamento de áreas potencialmente afectadas por um movimento de vertente, com base em cálculos probabilísticos.

O domínio das especificações técnicas desta primeira abordagem ao movimento de vertente de Armamar, obrigou a trabalhar a escalas de pormenor, concretamente, 1/10 000 e superiores. Entendemos que a localização deste fenómeno e a necessidade de trabalhar com grandes escalas vêm complementar o já longo (e acurado) trabalho que desde o OutonoInverno de 2000-2001 temos vindo a desenvolver nesta região do norte de Portugal. Assim, se as propostas iniciais para definição de modelos quantitativos e semi-quantitativos para o zonamento das susceptibilidades, vulnerabilidades e riscos tiveram por base escalas de precisão compreendidas entre 1/ 25000 e $1 / 50000$, na presente investigação não podemos deixar de destacar a informação de base, obtida na escala $1 / 10000$. O zonamento das áreas de risco assume, por isso, quase a feição de topozonamento, dado que é ao nível da vertente que temos de definir tarefas e métodos de análise morfométrica e morfodinâmica mas, também, de representação gráfica e cartográfica.

À semelhança do que havíamos feito para a área de Peso da Régua, folha 126 da Carta Militar de Portugal (CMP), na escala $1 / 25000$, a susceptibilidade - componente espacial do hazard - foi complementada com informação meteorológica e climática que, de algum modo, ajudou a definir valores críticos ou, pelo menos, a identificação de limiares a partir dos quais será de admitir o desencadeamento provável de manifestações de instabilidade nas vertentes da área em estudo. Foi, deste modo, contemplada também, a componente temporal do hazard, que fornece informação importante para a eficiência das estratégias de "alerta, prevenção e aviso - APA" - componente preventiva e de previsão, indispensável à mitigação do risco.

\section{Localizaçãoe descrição do Movimento Complexo de Armamar}

O movimento de vertente de Armamar (foto 4) ocorreu às 22 horas do dia 2 de Janeiro ao km $137+$ $300 \mathrm{~m}$ da estrada nacional (E.N.) 222 , na extremidade setentrional do Concelho de Armamar, distrito de Viseu. Trata-se de uma estrada marginal ao Rio

6) Risco (R)= Susceptibilidade (S) $\times$ Vulnerabilidade (V)];

$$
\mathrm{ACC}
$$

7) Risco (R)=f Susceptibilidade (S) $\times$ Vulnerabilidade (V)], ou seja,

$\mathbf{R}=\boldsymbol{f} \underline{\mathbf{H} \times \mathbf{V}}$. $\mathrm{ACC}+\mathbf{R I}$ $\overline{\mathrm{ACC}+\mathrm{RI}}$ 
Douro que, pela margem esquerda, liga a cidade de Peso da Régua à localidade de Pinhão talvez dois dos principais pólos de toda a dinâmica relacionada com a produção, transporte e comercialização do Vinho do Porto. Ocorrido numa vertente voltada a Norte (fig. 1), com perfil rectilíneo e com morfologia típica dos socalcos preparados para a vinha, o movimento de vertente de Armamar não teve, mas poderia ter tido, consequências verdadeiramente catastróficas, se pensarmos que apesar da enorme capacidade de destruição bem marcada nos cerca de sessenta metros de estrada destruídos, em toda a sua largura, só o acaso ditou que não tivesse havido consequências ao nível da perda de vidas humanas.

\section{Bases morfostruturais do suporte físico - factores condicionantes da estabilidade das vertentes}

Convém, antes de mais, recordar que estamos no coração do Alto Douro Vinhateiro, a primeira região vinícula demarcada do mundo, recentemente considerada património mundial pela UNESCO mercề da sua classificação como "Paisagem Evolutiva Viva". Trata-se, por isso, de um território cujos traços da paisagem traduzem, de modo impressionante, o diálogo permanente entre o Homem e o Meio, concretamente, entre o modo como o primeiro explora os recursos do segundo, extraindo-os directamente e/ou convertendo-os, e o modo como o segundo dos elementos referidos

Foto 4 - Localização do movimento de vertente de Armamar, 3 de Janeiro de 2003; dentro da circunferência (imagem da esquerda) encontram-se cerca de uma dezena de pessoas e uma viatura todo-o-terreno.
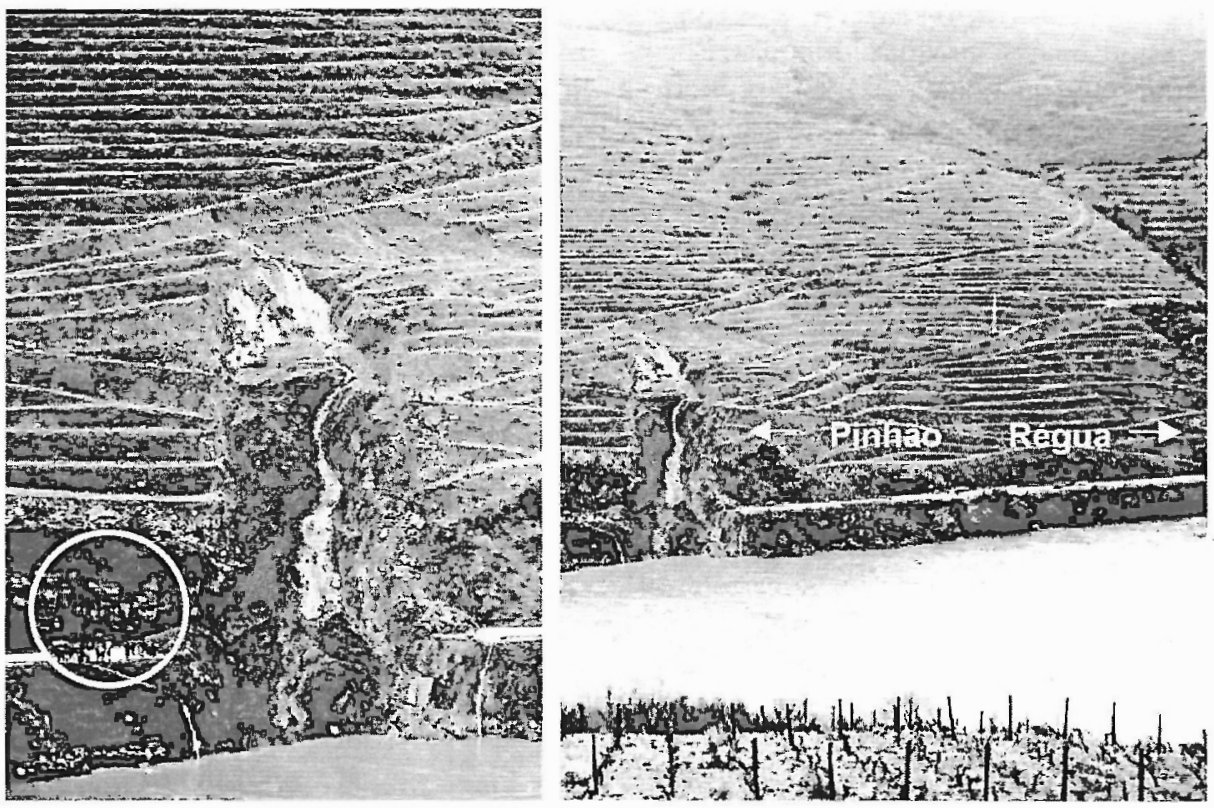

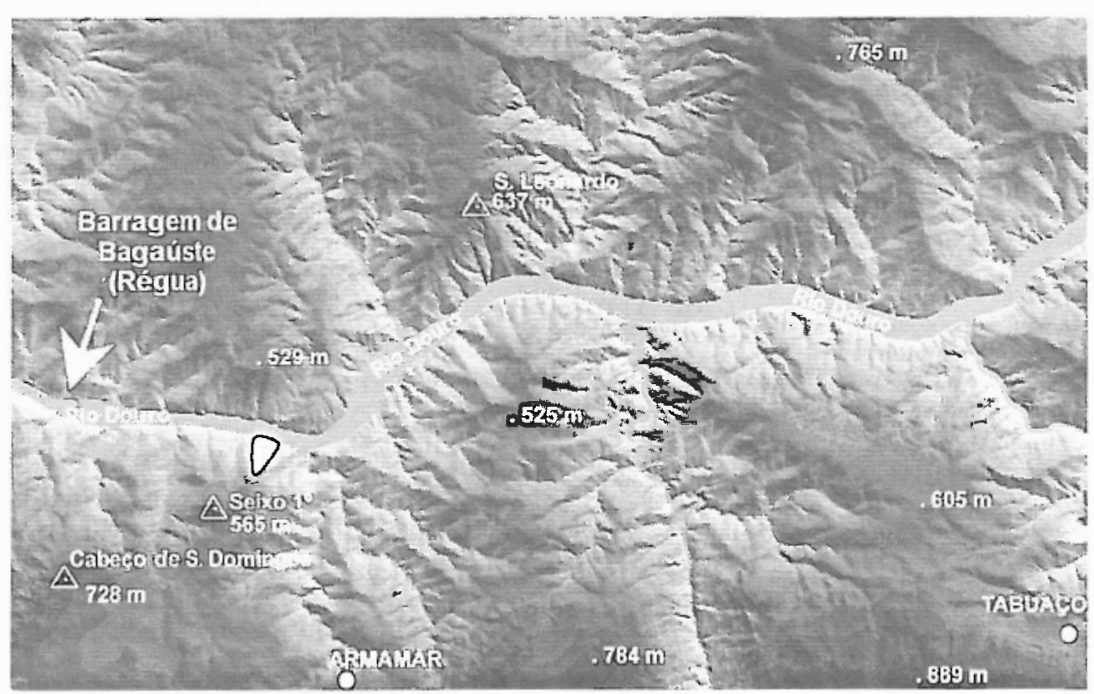

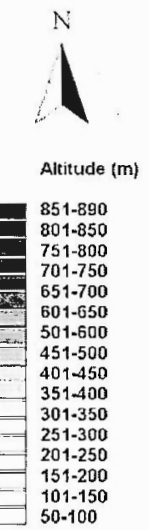

Figura 1 - Localização da componente de fluxo deslizante no movimento de vertente de Armamar (Modelo Digital de Terreno construído com base na Carta Militar de Portugal, Folha 127 - Tabuaço, 1/25 000). 
impõe, ao primeiro, condicionalismos diversos, por vezes, difíceis de contornar. Associados aos recursos encontramos, muitas vezes, os riscos, e ambos nos recordam os modos de vida das gentes ligadas ao vinho e à vinha que, entre outros factores estão dependentes do Rio e da sua rede de tributários, do clima, concretamente das características topoclimáticas, da morfologia, da estrutura do relevo mas, acima de tudo, do modo peculiar como nesta região todos os factores se conjugam.

A área onde ocorreu o movimento de vertente de Armamar é abrangida pela folha 10 - D (Alijó), da Carta Geológica de Portugal (CGP), na escala 1/50000. Oenquadramento geológico e morfotectónico desta área, no coração da Zona Centro-Ibérica (fig.2), destaca o predomínio da litologia metassedimentar que constitui o designado "Grupo do Douro" (B. SOUSA, 1982). Na notícia explicativa da referida folha geológica, os autores destacam também a relação existente entre a Geologia e o Vinho do Porto (B. SOUSA e A. SEQUEIRA, 1989). Nesta área, não é fácil encontrar verdadeiros condicionalismos litológicos à produção vinícula; no entanto, é quase sempre sobre afloramentos de materiais metassedimentares

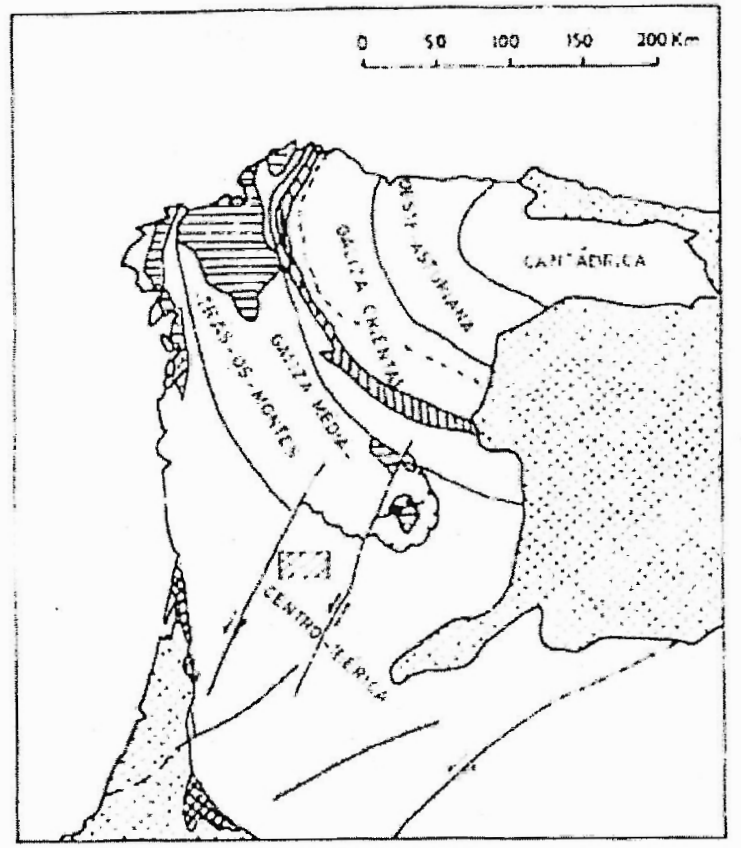

LEGENDA:

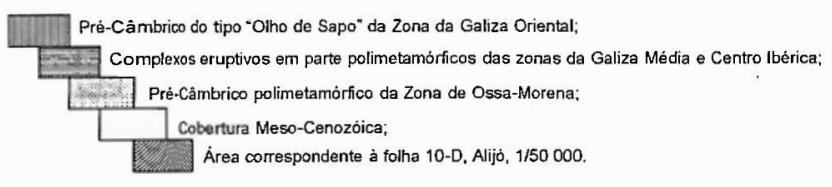

Figura 2 - Enquadramento paleogeográfico da área em estudo (Adaptado de Julivert et al., 1974, referido em B. SOUSA E A. SEQUEIRA, 1989). que vamos encontrar a implantação da vinha, como referem os autores, por vezes, quase coincidente com o contacto entre as rochas granitóides e as rochas xistentas.

O próprio discurso popular dos locais chega mesmo a referir-se a um terreno de "lousinha" como o que melhor se coaduna com a exigência do cultivo da vinha. A já referida folha geológica, da qual reproduzimos apenas o sector onde ocorreu o movimento de vertente de Armamar (fig. 3), evidencia a grande extensão ocupada pela litologia xistenta que caracteriza dois tipos de edifícios litostratigráficos câmbricos, por vezes, fortemente metamorfizados, e que estruturam grande parte do relevo trasmontano (B. SOUSA, 1982; SILVA \& RIBEIRO, 1985); trata-se das sequências Alóctone e Autóctone que, conjuntamente com outra unidade referida como "Parautóctone" - sem representação na área em estudo - constituem - Super-Grupo Dúrico-Beirão, representação local do anteriormente designado Complexo Xisto-Grauváquico Ante-Ordovícico. Na bacia do Douro, esta mega-unidade litostratigráfica, como anteriormente se referiu, recebeu a designação particular de Grupo do Douro (B. SOUSA, 1982).

Seguindo uma ordem geocronológica decrescente, a primeira das sequências referidas é constituída pela Formação do Rio Pinhão( ${ }^{(5)}$, pela Formação de Pinhão(6) , pela Formação de Desejosa ${ }^{(7)}$ e pela Formação de São Domingos ${ }^{(8)}$; a sequência Autóctone, também por ordem decrescente de antiguidade, é constituída pela Formação de Bateiras ${ }^{(9)}$ e pela Formação de Ervedosa do Douro ${ }^{(10)}$. Os materiais de natureza turbidítica cuja estrutura e disposição parecem prolongar-se para Leste, inclusivamente para Espanha, encontram-se muito bem caracterizados por B. SousA e A. SEQUEIRA (1989) na notícia explicativa da folha 10-D (Alijó) da CGP. Os autores justificam as designações adoptadas alertando para a dicotomia introduzida (Autóctone-Alóctone) na medida em que, ao cartografarem a folha 15-A (Vila Nova de Foz Côa) da CGP na mesma escala (SILVA \& RIBEIRO, 1985), "inferem a presença de um acidente cavalgante na região de Senhora do Viso-ocarreamento sin-sedimentar da Senhora do Viso - pressupondo a implicação que para ocidente (...) haja duplicação tectónica no Grupo do Douro, isto é, equivalência entre a Formação de Ervedosa (autóctone) e a Formação de Pinhão (alóctone), e equivalência (com passagem

\footnotetext{
(5) Metagrauvaques com intercalaçöes de filitos listrados e microconglomerados.

(6) Filitos cloríticos, quartzo-cloríticos e metaquartzovaques, com magnetite (7) Filitos listrados com interçalações de metagrauvaques.

(8) Conglomerados com metaquartzarenitos e metaquartzovaques.

(9) Alternância de xistos listrados com metaquartzovaques com intercalações de calcários; xistos negros, grauvaques e microconglomerados.

(10)Filitos cloríticos, quartzo-cloríticos e metaquartzovaques; com magnetite e com microconglomerados.
} 
lateral de facies) entre a Formação de Bateiras (autóctone) e a Formação de Rio Pinhão (alóctone)". A observação atenta da figura 3 , permite constatar que os afloramentos metassedimentares se encontram delimitados por intrusões de rochas granitóides que estão na génese das antiformas de Vila Real-Carviçais (na bordadura Norte da carta) e de Lamego-Penedono-Escalhão (na bordadura Sul). Em ambos os casos, parece tratar-se de granitos tardi-orogénicos da fase $\mathrm{F}_{3}$ hercínica.

Descendo na escala espacial de análise, o movimento de vertente em questão ocorreu nos materiais metassedimentares da Formação de Pinhão que, localmente, evidenciam um franco enriquecimento em magnetite que se traduz pelo aspecto mosqueado da litologia. No campo identificámos uma "estratificaçãodas bancadas metassedimentares" com inclinação oposta em ambas as margens do Douro (fotos 5, 6A e 6B), ideia que pudemos confirmar com a observação da folha 10-D da CGP. Pensamos, por isso, que o Douro deverá ter-se adaptado à estrutura com o seu leito a encaixar na charneira de um pequeno sinclinal definido já muito próximo do contacto com a antiforma de Lamego-Penedono-Escalhão. Aquela sinforma deverá integrar uma estrutura mais ampla e complexa, em sinclinório (cfr. corte geológico, fig. 3), existente entre as duas referidas antiformas, estrutura que parece estar francamente recortada por falhas cavalgantes, por vezes, com carreamentos, mas também por desligamentos com movimentação horizontal (strike slip faults), geralmente, com movimentação esquerda (cfr. fig.2).

Os materiais'da Formação de Pinhão revelam uma constância bastante acentuada das suas propriedades (B. SOUSA e A. SEQUEIRA, 1989). De acordo com os autores, estes materiais apresentam uma coloração esverdeada característica de toda a sequência, e uma ritmicidade caracterizada pela alternância de leitos psamíticos (quartzosos), predominantemente metaquartzovaques e quartzitos impuros, mais raramente metagrauvaques, e pelíticos (filíticos) que, de um modo mais geral, correspondem ao par metaquartzovaques - filitos cloríticos.

Um dos aspectos que consideramos mais importantes para a caracterização da litologia da área onde ocorreu o movimento de vertente de Armamar, reside
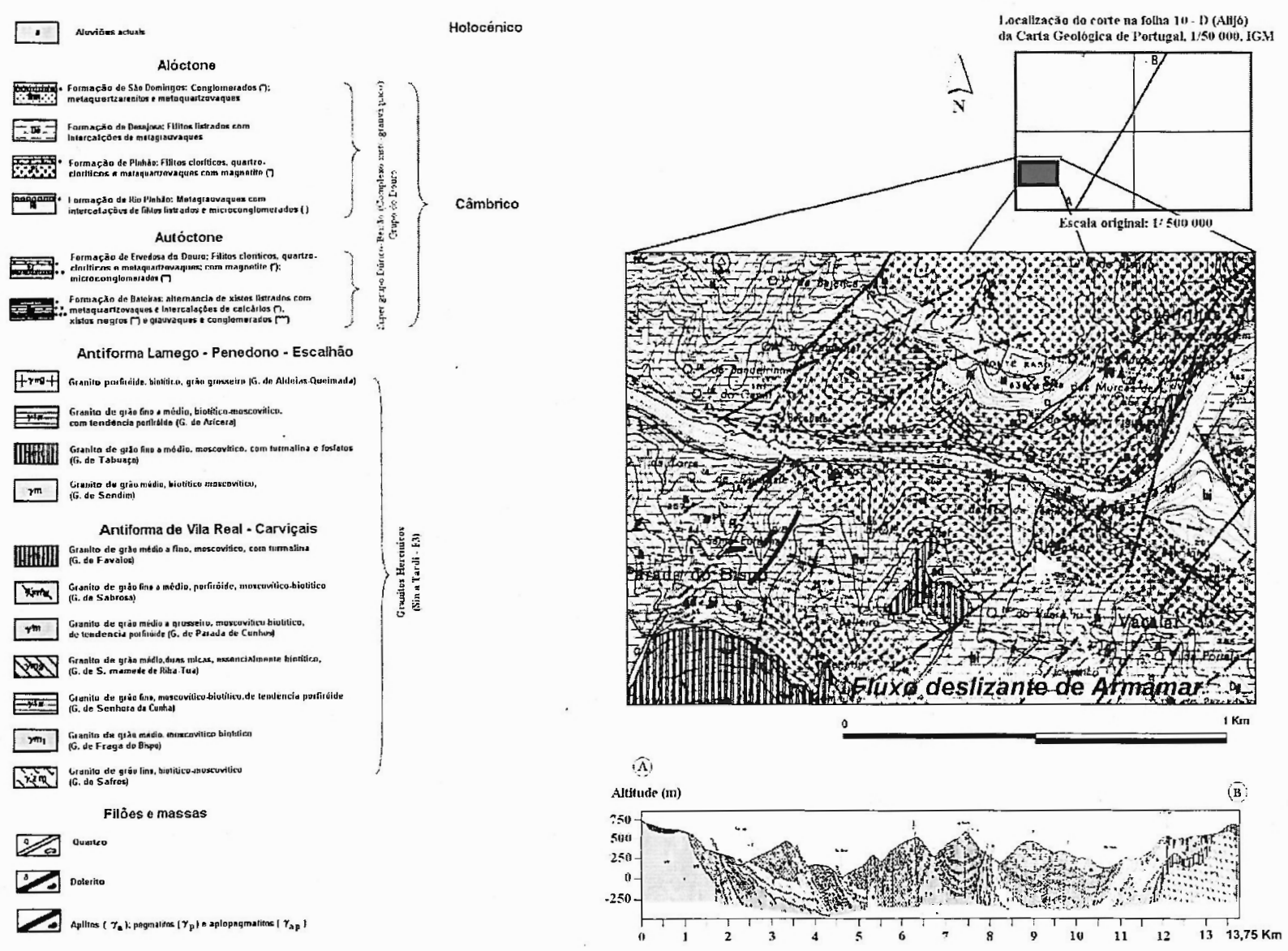

Figura 3 - Contexto morfostrutural do Fluxo deslizante de Armamar (Adaptado da Folha 10 - D, Alijó, da CGP, 1/50 000). 


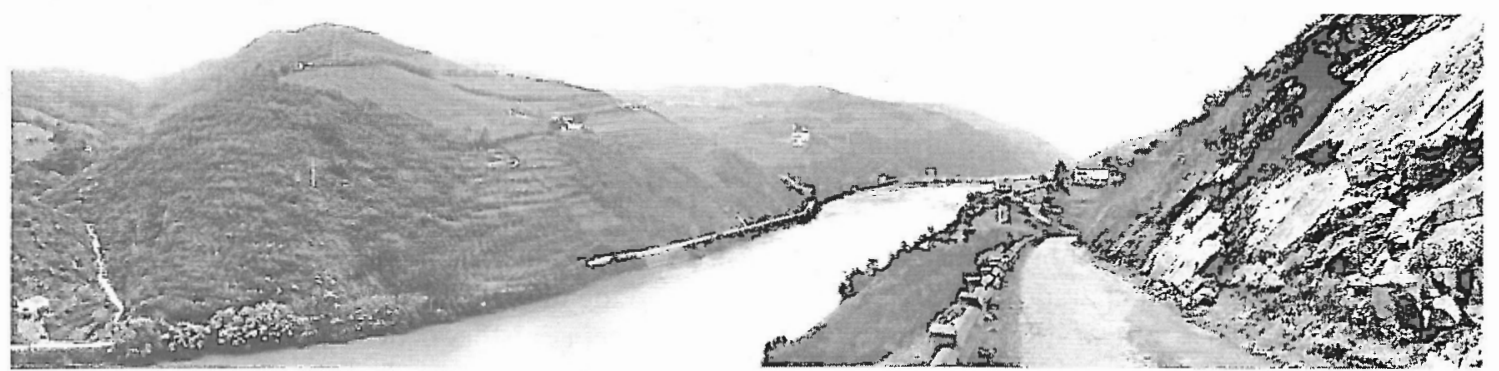

Foto 5 - Disposição estrutural das bancadas de metaquartzovaques com magnetite, disponibilizando verdadeiras rampas de deslizamento de materiais, coerentes ou detríticos (Visto para Ocidente, a montante da Barragem de Bagaúste - Régua).
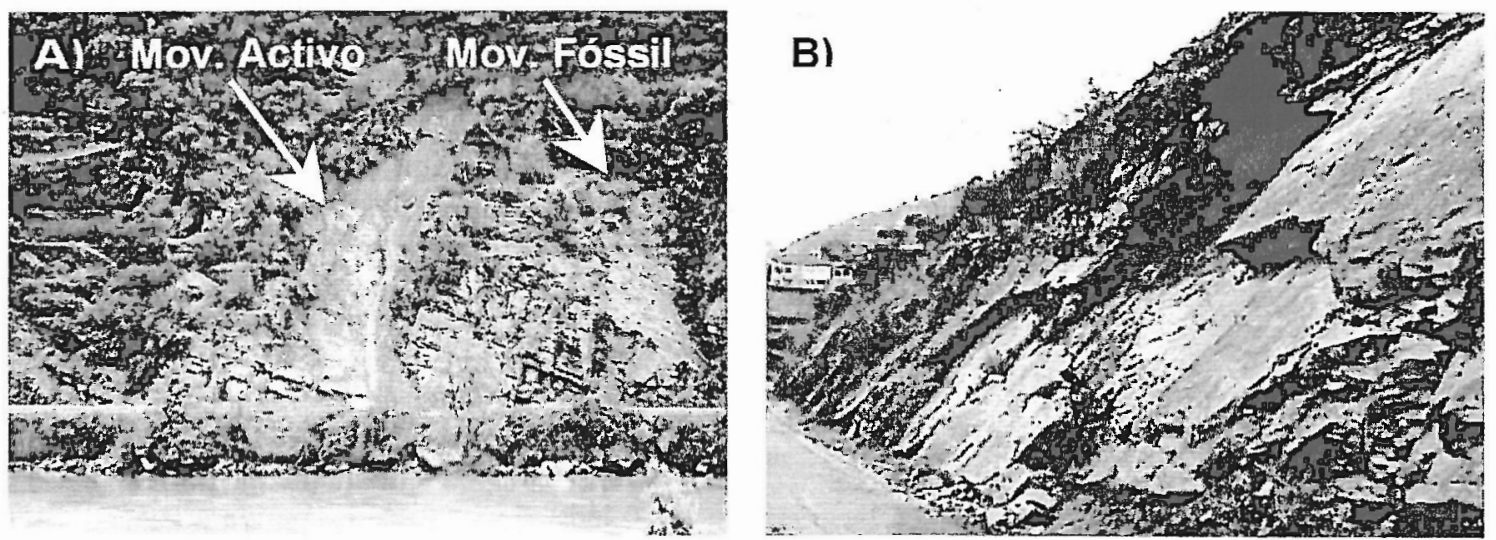

Foto 6 - A) Movimento activo em materiais detríticos assentes, em descontinuidade, sobre as bancadas metassedimentares, lado-a-lado com um movimento fóssil, ambos na margem esquerda do Douro, na E.N. 222; B) Note-se a existência de planos de descontinuidade favoráveis à ocorrência de deslizamentos planares de blocos (rock block slide) ou de mecanismos do tipo "Buckling" - caso particular dos deslizamentos planares de blocos que envolve placas fracturadas, na margem direita, em sectores onde não há cobertura detrítica.

no facto de os leitos de metaquartzovaques, geralmente mais finos, serem também mais resistentes, pelo que a resposta da morfologia se traduz pela definição de formas salientes na topografia da vertente formando, por vezes, autênticas "cornijas" ou mesmo linhas de crista salientes na paisagem. A maior resistência destes materiais à acção mecânica da erosão, designadamente, quando comparados com as bancadas filíticas, e quando aliada à inclinação das bancadas e ao contexto morfotectónico que ajudou a definir a estrutura apresentada pelo Grupo, em geral, e esta sequência, em particular, permitem identificar um quadro morfostrutural francamente favorável à ocorrência de movimentos de vertente, de pequena ou mesmo de média dimensão, isto é, de dimensão "métrica a decamétrica" e "hectométrica", respectivamente. Concretizando, constatámos no terreno, a existência de planos de descontinuidade litostratigráfica que favorecem a ocorrência de deslizamentos planares (cfr. foto $6 \mathrm{AeB}$ ) eidentificámos áreas mais susceptíveis à queda newtoniana de grandes blocos rochosos salientes no topo de algumas vertentes. Quando estas bancadas se encontram sobrepostas por uma cobertura, geralmente de textura argilosa, silto-argilosa ou areno- -argilosa, resultante de alteração da rocha, de depósito ou simplesmente porque oHomem para lá a transportou, as condições morfostruturais tornam-se favoráveis à movimentação rápida da cobertura detrítica suprajacente (cfr. fotos $1 \mathrm{~A} \mathrm{e} \mathrm{B} \mathrm{e} \mathrm{6A).} \mathrm{Estes} \mathrm{materiais,} \mathrm{geralmente}$ referidos como "loose material" na literatura anglógrafa, são pouco compactos e pouco coesos, e instabilizam com facilidade. Em favor de um plano de descontinuidade que se estabelece no contacto entre a referida cobertura detrítica e a rocha coerente, geralmente impermeável com excepção de contextos caracterizados por uma grande densidade ou intensidade de fracturação, os factores considerados como "desencadeantes" de condições de instabilidade nas vertentes encontram nestas áreas um quadro susceptível de culminar em situações de desastre, de que o movimento de vertente de Armamar, no seu conjunto, e a componente de Fluxo deslizante, em particular, constituem o mais recente exemplo. Este fenómeno constitui, por outro lado, a mais fiel, didáctica e recente demonstração pública da necessidade de transição de uma "cultura reactiva" para uma "cultura preventiva", conduta tão fortemente sublinhada pela International Decade for Natural Disaster Reduction (IDNDR) 
e à qual também já por diversas vezes nos referimos. Fundamentada em estudos científicos interdisciplinares bem articulados, esta forma de pensar o Planeamento e o Ordenamento do território permite pôr em marcha, em tempo útil, as diversas e complexas tarefas de "Prevenção e Aviso" (Early warning) sem as quais não se consegue proteger as populações, fïm último ou primeiro - dependendo da perspectiva de análise - de quem decide e põe em prática as tarefas de Planeamento e Ordenamento. No final deste curto apontamento geológico, confrontamo-nos com a questão do Ordenamento integrado e interrogamonos se o verdadeiro e decisivo contributo para o Desenvolvimento sustentado não deverá passar pela articulação de fontes de informação de natureza diversa, na qual se inclui, necessariamente, a Cartografia de susceptibilidades, de vulnerabilidades e de riscos, o mesmo será interrogarmo-nos, sobre a importância do enfoque desta questão nas tarefas operacionais executáveis a montante dos problemas.

\section{Factores Geomorfológicos}

\section{O contexto regional}

A localização do essencial da área abrangida pelo Alto Douro Vinhateiro impõe que recordemos o contexto estrutural anteriormente apresentado, do qual sobressai a presença de uma mancha de rochas xistentas (Grupo do Douro) delimitada pelos dois afloramentos graníticos, já referidos, que dão corpo à ossatura das antiformas Vila Real-Carviçais e Lamego-Escalhão, respectivamente a Norte e a Sul do Douro. A erosão diferencial assume, por isso, um papel importante na explicação do modelado mas não deixa, no entanto, de sublinhar o controlo tectónico e a sua reactivação quaternária ao qual se tem de recorrer para compreender o forte encaixe do Douro mas, acima de tudo, de algumas pequenas linhas de água que de outro modo talvez não tivessem conseguido acompanhar a evolução vertical da drenagem.

A identificação de possíveis níveis de aplanamento, quer pela existência de amplas formas aplanadas no topo das vertentes, de ressaltos topográficos e de rupturas de declives a altitudes semelhantes, em vertentes e nos perfis longitudinais de várias linhas de água, poderão constituir bons indicadores morfológicos para se ensaiar uma proposta de evolução recente do relevo neste sector da bacia do Douro. No entanto, alguma prudência deve ser colocada nesta abordagem, pelo que deve ser complementada com outros tipos de informação, designadamente geológica, na medida em que o comportamento erosivo diferenciado das categorias litológicas em confronto induz, de modo muito provável, uma evolução morfológica das vertentes nelas talhadas que não tem necessariamente de se traduzir pela definição de verdadeiros "níveis" localizados, necessariamente, às mesmas altitudes, independentemente do tipo de rocha. Por outro lado, a construção repetida e generalizada de rupturas de declive não se verifica rigorosamente às mesmas altitudes em vertentes graníticas e em vertentes talhadas nos filitos do "Grupo do Douro". Associadas à pouca informação existente sobre registo sedimentar e estratigráfico cenozóicos, estas reflexões legitimam a reapreciação dos níveis de aplanamento propostos (BRUM FERREIRA, 1978), para esta área, níveis que o Autor denomina "Níveis do Douro".
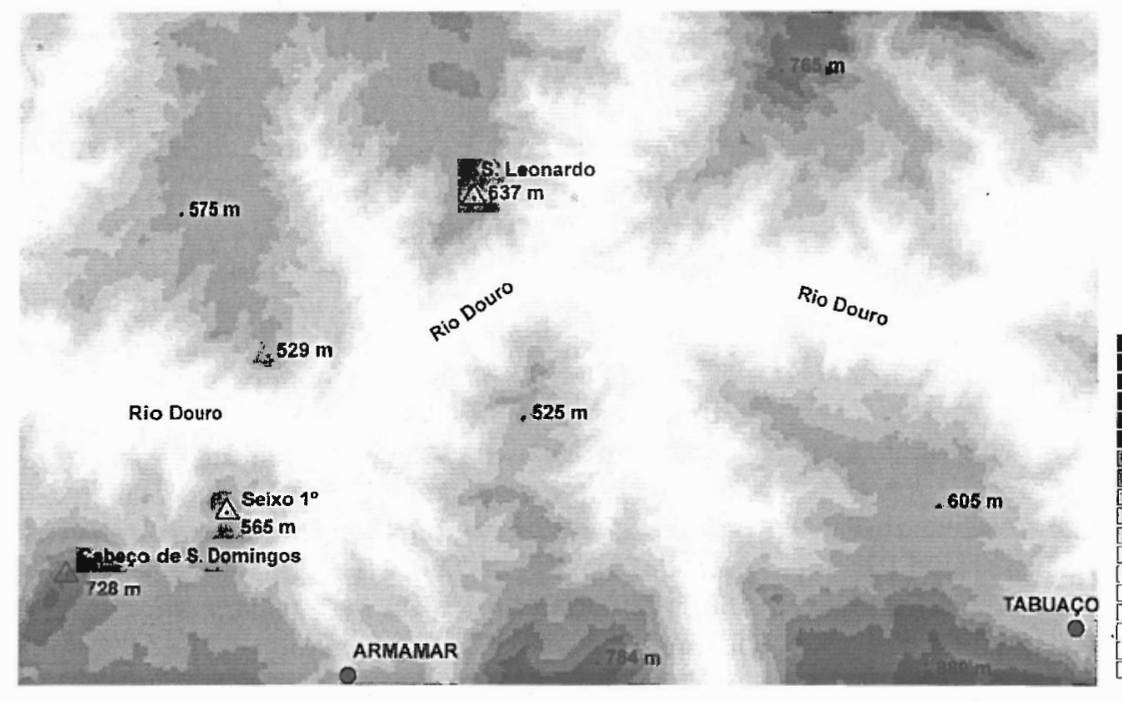

Figura 4 - Esboço hispométrico da área abrangida pela Folha 127, com escala $1 / 25000$, da CMP. 
Figura 5 - Representatividade gráfica do valor areal das classes de altitude para a folha 127 da CMP, $1 / 25000$.

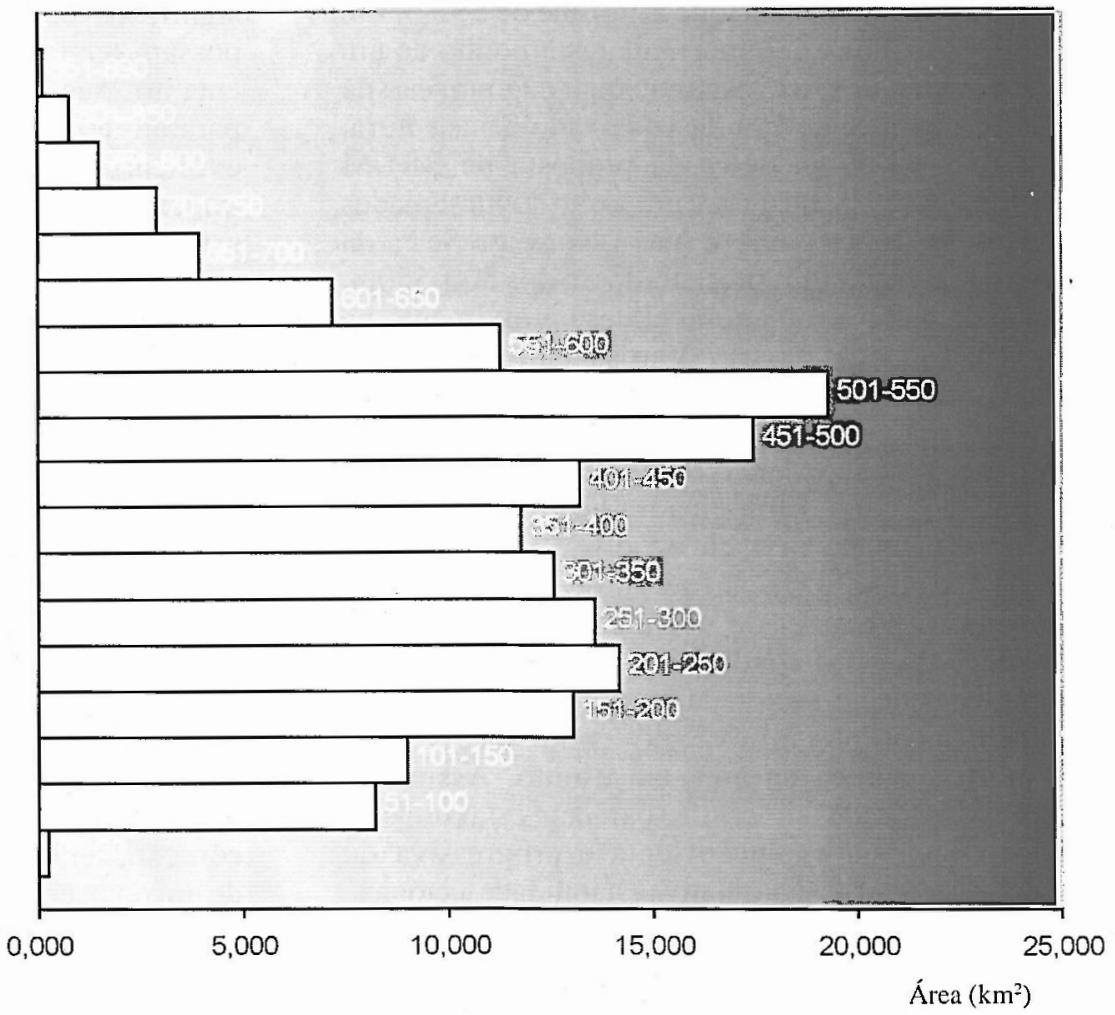

A análise das figuras 4 e 5 permite-nos pensar que a existência de pequenos retalhos aplanados a altitudes compreendidas entre valores que rondam os $900 \mathrm{~m}$ - Superfície fundamental - referida por BRUM FERREIRA (ob. cit., 115 e seg.) e o nível de aplanamento dos $550-600 \mathrm{~m}, \mathrm{~m}$ poderão constituir testemunho de pequenos níveis de aplanamento intermédios ${ }^{(1)}$, incompletos, hipótese para a qual não reunimos dados coerentes que permitam esclarecer o seu valor documental. Pensamos, contudo, que a reduzida informação sobre o registo sedimentar correlativo dos referidos aplanamentos autoriza que se pense numa hipótese alternativa que residiria na possibilidade de constituírem pequenos retalhos que coroam o topo de algumas vertentes $\leq$, deslocadas verticalmente ou que localmente sejam constituídas por materiais mais resistentes. Por outro lado, os

(I I) Referida por B. SOUSA e A. SEQUEIRA (1989), a superfície dos 600$650 \mathrm{~m}$ parece não ter grande representatividade morfológica, em termos de extensão, na área em estudo (recorde-se que representa apenas um quarto da área abrangida por aquela folha da CGP). No entanto, parecenos que a ideia do forte encaixe do Douro e dos seus afluentes avançada pelos mesmos autores, também parece ganhar alguma força na interpretaçãodas figuras anteriores, ideia que poderiajustificar a escassez de aluviões, devido à intensa erosão remontante do Douro que caracteriza uma fase ou, se se preferir, um conjunto de fases quaternárias em que a giiptogénesedeveráter sido predominante em relação à sedimentogénese, acção que poderá ser extrapolada ao conjunto da bacia, após a captura da drenagem endorreica do Douro e inflexäo do sentido geral do escoamento para Ocidente, para o Atlântico. declives acentuados (fig. 6), que sucedem ao aplanamento de alguns topos em direcção à base da vertente, parecem ter correspondência na transição dos afloramentos graníticos para as séries metassedimentares. A frescura de algumas escarpas com sectores rectilíneos e declives acentuados (quase autênticas paredes sub-verticais), os lineamentos definidos pela confluência de algumas linhas de água afluentes do Douro e a existência de desníveis que, em alguns casos, chegam a atingir um comando vertical de cerca de $300 \mathrm{~m}$ em sectores muito próximo da área em estudo ${ }^{(12)}$, induzem uma leitura dạ evolução recente das formas de relevo, onde a movimentação vertical de blocos parece ocupar um importante lugar. Em harmonia com esta interpretação destaca-se, também, a existência de imponentes escarpas, provavelmente de falha, com sectores facetados de feição triangular (fig. 7), sectores que parecem reforçar a hipótese de movimentação vertical recente de alguns blocos em confronto.

Em termos de interpretação dos condicionalismos climáticose morfostruturais à dinâmica geomorfológica das bacias fluviais e de sedimentação, concretamente neste sector ocidental da bacia do Douro, destacamos a importância dos valores de altitude correspondentes às classes $451-500 \mathrm{~m}$ e $501-550 \mathrm{~m}$ (cfr figs. 4 e 5 ).

(12) Refere-se o exemplo de Trevões, onde a Serra de Sampaio, localizada a ESE de Tabuaço, atinge a cota de $935 \mathrm{~m}$ e domina um amplo desnivel com uma altitude em torno de 600-650m (BRUM FERREIRA, 1978, 124). 
A figura 5 sugere mesmo que a altitude de $501-550 \mathrm{~m}$ poderá constituir um importante testemunho de um nível de aplanamento a partir do qual o Douro e a sua rede de afluentes deverá ter encaixado na estrutura, ideia que vai ao encontro da proposta de BRUM FERREIRA(1978)quando, a propósito dos designados "Níveis do Douro", refere que a Norte da Serra da Nave o nível melhor representado é o dos 500-550m, chegando a atingir um notável desenvolvimento na margem esquerda do rio Varosa entre Penude e Lamego, área que não é abrangida pela superfície cartografada na folha 127 (Tabuaço) da CMP. Por este motivo, nãose podedeixar de destacar a importância da dinâmica geomorfológica traduzịda pela grande extensão ocupada pela classe dos 501-550m (cfr. fig. 5) que poderia mesmo servir de referência para a definição provável de um marco importante na caracterização dos condicionalismos (estruturais e climáticos) deste sector da bacia do Douro, logo, também, na própria inflexão do sentido da evolução da morfodinâmica da área em estudo. Assim, os valores de altitudes superiores parecem estar relacionados com uma evolução lenta e progressiva do modelado, coeva de uma relativa estabilidade tectónica, onde o entalhe vertical não deverá ter sido muito significativo, exceptuando as condições locais que possam ter favorecido esta acção. Estranha-se, no entanto, que este contexto morfológico não tenha paralelo ao nível morfossedimentar o que só pode explicar-se pela acentuada acção gliptogenética traduzida pelo rápido desmantelamento das vertentes e de eventuais registos sedimentares cenozóicos que ali possam ter existido, o que poderá explicar a menor expressão das classes de altitude inferiores a $500 \mathrm{~m} \mathrm{e}$ a ausência dos referidos depósitos.

O aumento progressivo da área ocupada pelas classes de altitude compreendidas entre os 350 e os $201 \mathrm{~m}$ (cfr. fig. 5) poderá significar uma inversão da tendência rexistásica que deverá ter culminado numa nova fase de estabilidade morfodinâmica que ajudaria a compreender a significativa extensão da área definida a altitudes compreendidas entre $201 \mathrm{e} 250 \mathrm{~m}$, sugerindo, assim, uma nova fase de estabilidade favorável à sedimentação - da qual também não se conhecem registos significativos. Esta fase poderá ter marcado uma nova inflexão da acção geomorfológica com tendência para o acentuar de um ambiente, novamente, com características rexistásicas, favoráveis à definição de um novo encaixe da rede hidrográfica na estrutura e ao ataque progressivo às formas de relevo com

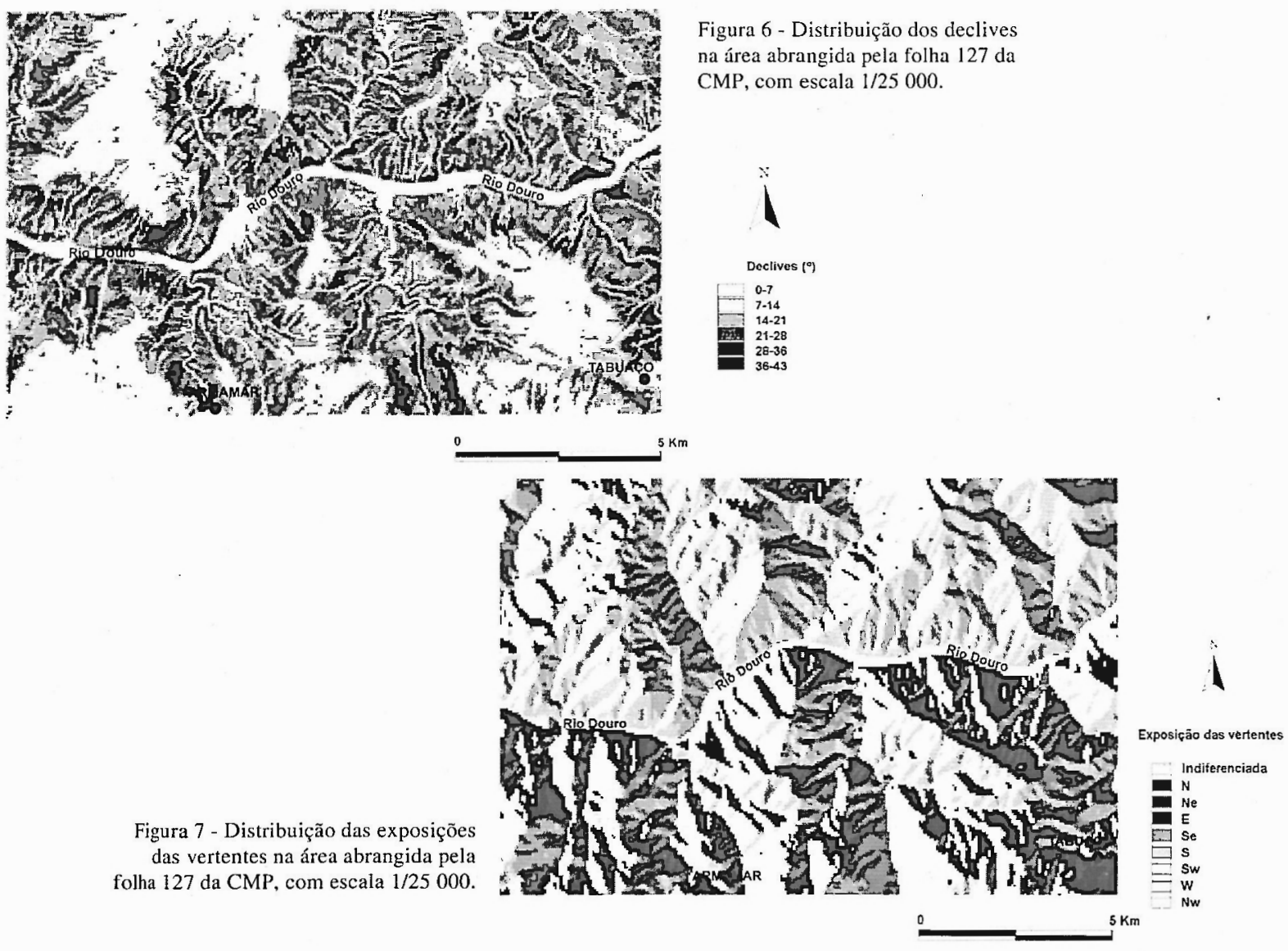


altitudes mais próximas do actual traçado das principais linhas de água. No pormenor, talvez esta leitura seja demasiado simplista mas a observação atenta da figura 5 e os dados recolhidos, no terreno e no gabinete, legitimam uma interpretação que permite destacar apenas dois momentos que poderiam corresponder a dois dos designados "Níveis do Douro" (501-550m e 201-250m) que estariam escalonados entre os 900 metros da Superfície Fundamental e o nível actual do talvegue do Rio. Pensamos que não tendo correspondência absoluta com indicadores geomorfológicoscomo rupturas de declive nas vertentes e nos perfis longitudinais das linhas de água, e não tendo, sobretudo, o reforço do testemunho morfossedimentar correlativo da sua génese provável, os restantes níveis identificados pelo Autor poderão ser justificados com outro tipo de factores relacionados, designadamente, com a tectónica e com a erosão diferencial de acordo com a reflexão que se apresenta.

$\mathrm{O}$ desenvolvimento dos diferentes (e eventuais) níveis de aplanamento incompletos, aqueles que, em nosso entender não assumem expressão significativa independentemente do tipo de rocha, poderia ser justificado por duas ordens de razões principais: a primeira, de carácter mais geral está relacionada como os condicionalismos resultantes dos factores que controlam os ambientes de sedimentação, oscilações glácio-eustáticas, variações climáticas e dinâmica tectónica (global, regional e, mesmo, local) que, entre outras consequências, se reflectem na morfologia, morfometria morfodinâmica das bacias sedimentares, nas formas do modelado, em geral, e no traçado dos cursos de água, em particular; a segunda ordem de razões deverá poder relacionar-se com as diferenças na constituição litológica e composição petrográfica e mineralógica dos materiais em confronto, assim como na densidade, tipo e grau de fracturação que, no pormenor, afectam ambos os materiais. Alguns destes parâmetros podem ser inclusivamente inferidos através de foto-observação e foto-interpretação de fotografia aérea ou de análises de modelos digitais de terreno (cfr. fig. 1).

A presença dos granitóides não ocupa grande extensão na área em estudo, destacando-se, pelo contrário, a grande mancha ocupada pelos afloramentos metassedimentares. Pensamos, por isso, que a diferenciação interna do grau de resistência destes materiais, concretamente na Formação de Rio Pinhão, Formação de Pinhão e Formação de Desejosa que, conjuntamente com a Formação de São Domingos estruturam a anteriormente referida sequência alóctone trasmontana, em concurso com a rede de fracturas, deverão estar na origem, quer da orientação dos principais interflúvios e talvegues, quer no grau de desenvolvimento da componente estrutural sugerida para a génese de algumas plataformas. Contudo, fazemos notar que a existência provável de um eventual nível de aplanamento, testemunho de uma fase de maior acalmia tectónica, também poderia encontrar aqui raízes para o seu fundamento, na medida em que a grande extensão que ocupa permite pensar que se deverá ter desenvolvido nas três formações de base do alóctone anteriormente referidas (cfr. fig. 3). Mais do que a densidade da fracturação que, localmente, poderá afectar todos estes materiais, pensamos que a diferente composição mineralógica e petrográfica intrínseca

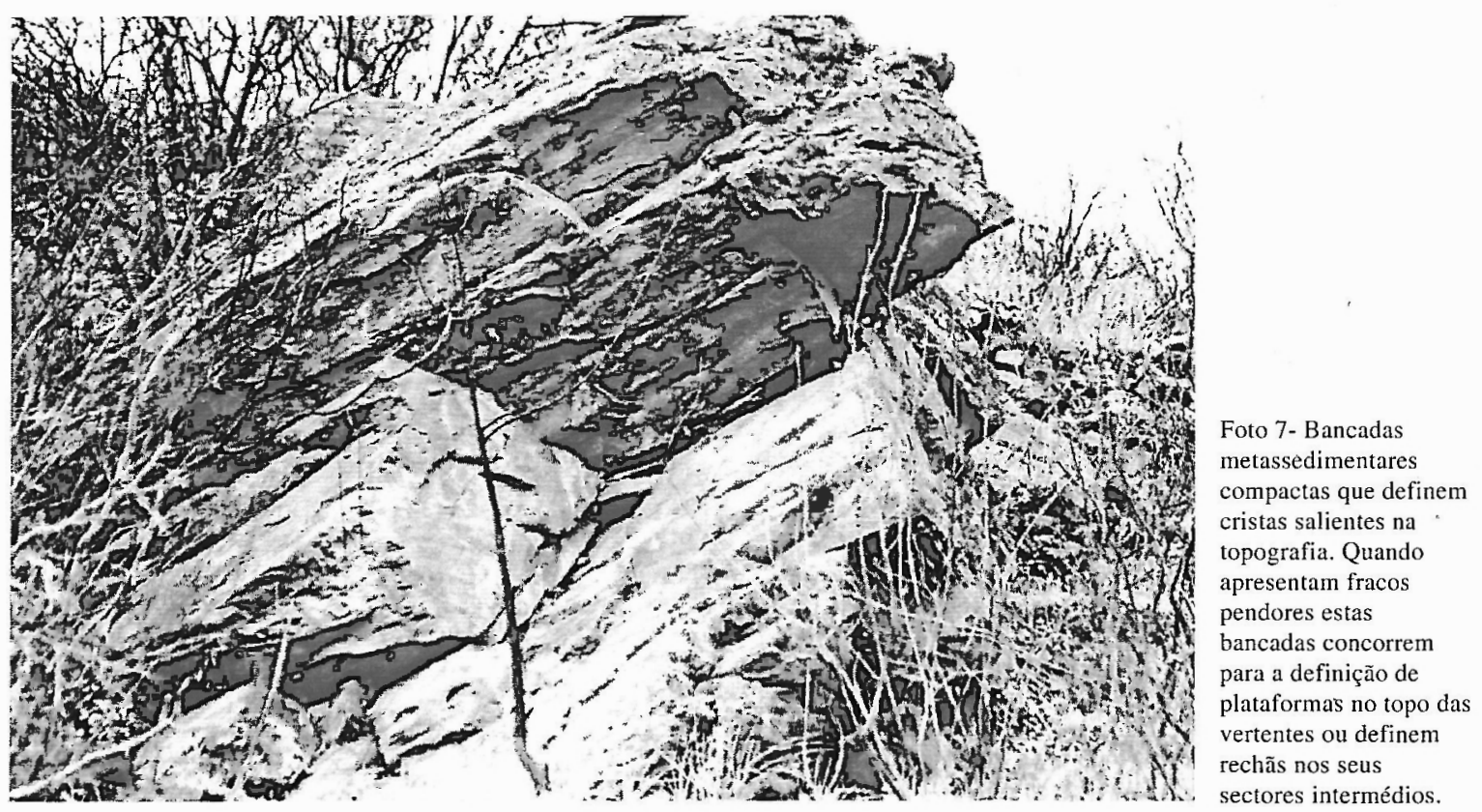


às diferentes facies metassedimentares em confronto poderão explicar - talvez melhor - o aparecimento de formas topograficamente salientes (foto 7), mas também o desenvolvimento mais acentuado das formas aplanadas a estas altitudes (cfr. figs. 4, 5).

Este parâmetro geomorfológico parece reforçado pelo desnível, também, de $300 \mathrm{~m}$ entre o topo das vertentes talhadas na bordadura granítica da carta nas proximidades de Tabuaço e o nível dos 550$-600 \mathrm{~m}$, que se encontra bem desenvolvido no edifício metassedimentar. No entanto, admitimos que, numa análise de pormenor, também alguns leitos mais competentes do conjunto metassedimentar, que surgem intercalados no essencial do Grupo do Douro, possam dificultar o remontar de cabeceiras de algumas linhas de água. Este facto explicaria o relativo insucesso de algumas dessas linhas deágua na tentativa de acompanhar o encaixe mais ou menos generalizado da rede de drenagem do Douro e a sua consequente posição alcandorada relativamente ao curso principal, contexto que se verificaria assim, quer em afloramentos granitóides (foto 8), quer em áreas metassedimentares mais competentes (foto 9), onde, para além de valeiros alcandorados, se podem encontrar também rupturas de declive bem marcadas na paisagem nas quais evoluem pequenas cascatas de dimensão métrica a decamétrica.

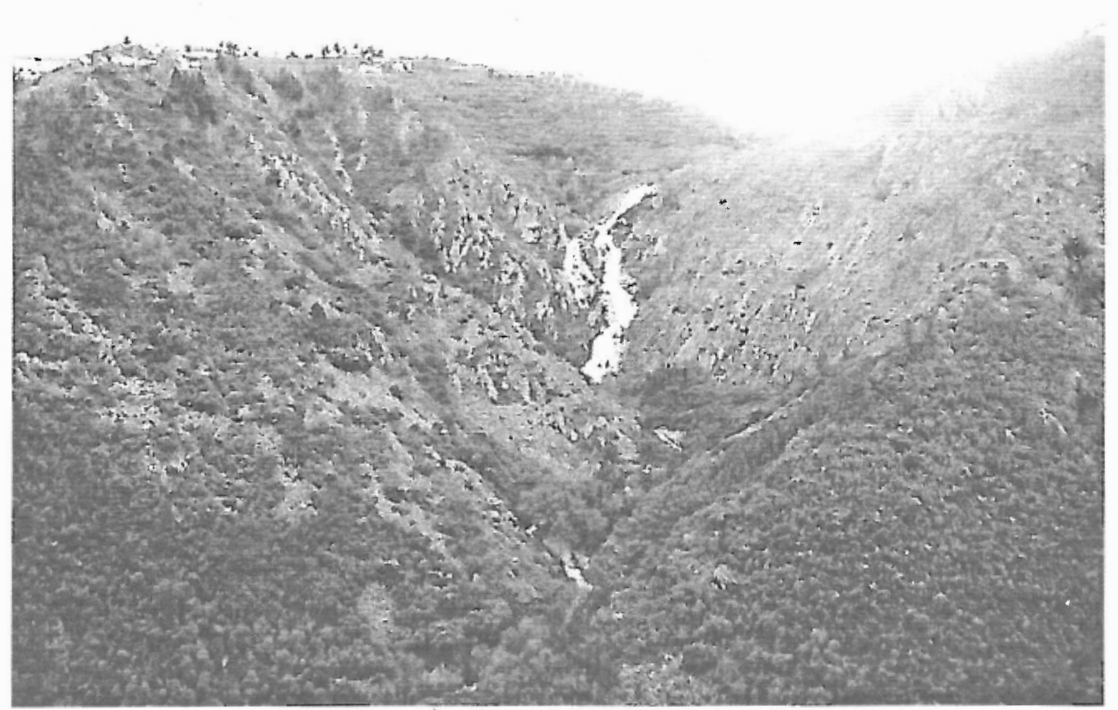

Foto 8 - Cabeceiras graníticas da ribeira de Temilobos a jusante de Armamar (vista para Sul).

Foto 9 - Queda de água em afloramentos metassedimentares de um afluente na margem esquerda do Douro, a montante da barragem de Bagaúste.

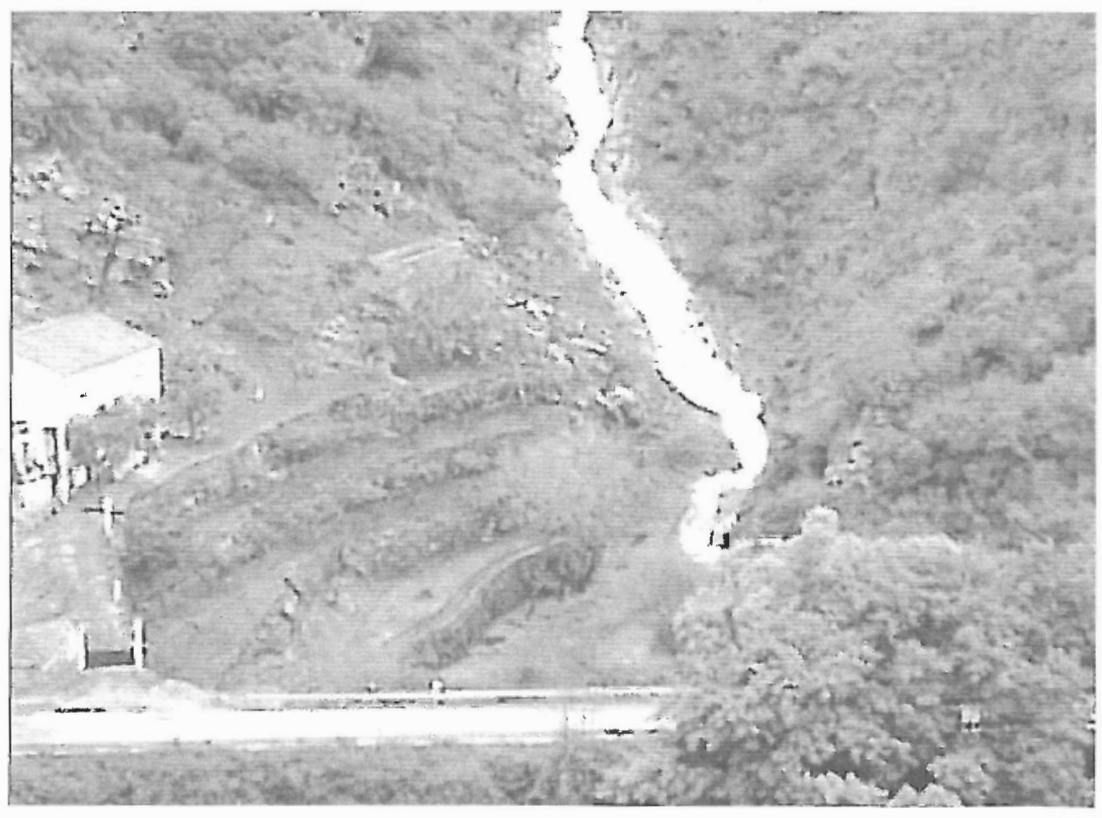




\section{O contexto local; da dinâmica complexa do Movimento à análise de pormenor da compo- nente de Fluxo deslizante}

\section{Parâmetros morfodinâmicos}

Como anteriormente referimos, o movimento de vertente de Armamar apresenta características morfodinâmicas e actividade complexas pelo que, numa primeira abordagem, não pode deixar de ser vinculado a esta categoria de movimentos no sentido inicialmente atribuído por VARNES $(1978,1984)$, referidoem 1993 pela WORKINGPARTY ONWORLD LANDSLIDE INVENTORY (WP/WLI) e adoptado por DIKAU et al. (1996) e CRUDEN \& FELL (1996). Esta proposta restringe a utilização do termo "complexo" a situações bem definidas em que se torne possível individualizar, na mesma sequência cronológica, mais do que um tipo de mecanismo actuante. Já o termo "compósito" deveria ser utilizado sempre que um movimento de vertente apresenta pelo menos dois mecanismos, em simultâneo, responsáveis pelo deslocamento de materiais em sectores diferenciados no conjunto do material afectado. Conforme relata ZÊZERE (2000) nem sempre é fácil, no terreno, distinguir entre um "movimento complexo" e um "movimento compósito" devido à dificuldade em identificar sequências temporais no desenvolvimento do movimento, particularmente quando a data de levantamento de campo não coincide com o seu período de actividade. Neste caso, admitimos que o essencial do material deslocado tenha sido inicialmente instabilizadopor um mecanismotangencial do tipo deslizamento rotacional com perfil ligeiramente côncavo, localizado nas cabeceiras do movimento, ou por um simples desabamento de dimensão métrica. Qualquer uma destas possibilidades deverá ter definido uma cicatriz à qual se ligaria posteriormente a cicatriz principal de um movimento planar em bloco (cfr. foto 9) a favor de um plano de descontinuidade e da própria conformidade existente entre o pendor das bancadas de metaquartzovaques com magnetite que surgem intercaladas no essencial da série de filitos cloríticos e quartzo-cloríticos (Formação de Pinhão, cfr. fig. 3) e o declive da vertente. No pormenor, o movimento de vertente de Armamar assumiria, assim, uma tipologia "complexa", na medida em que pelo menos três tipos de mecanismos deverão ter afectado o material deslocado, em momentos temporalmente distintos e em sectores bem individualizados na vertente; por um lado, um sector que consideramos ter sido o corpo do movimento onde ocorreu um mecanismo com forte componente fluxiva, concretamente, do tipo "fluxo deslizante" (fotos 10 e 11), enquanto que, em posição lateral à área de arranque do mecanismo principal, decorridas apenas algumas horas após o acidente, nas cabeceiras do movimento pudemos comprovar a existência de um mecanismo do tipo deslizamento planar (foto-11) denunciado pela definição de amplas fendas de retracção a montante (foto 12). Localizadas ao longo do plano de ruptura, estas fissuras ou estrias que os autores anglófonos designam por "slickenslides", constituem bons indicadores morfológicos da direcção da deslocação (CARCEDO-AYALA, 1991). Para além da componente fluxo deslizante (que considerámos a principal no conjunto do movimento) o referido mecanismo translacional afectou também uma área significativa da vertente (cfr. foto 11).

O controlo estrutural e a presença de meios anisotrópicos são, como referimos, argumentos importantes para podermos admitir a participação componente translacional e não rotacional. Autores como NEMCOK (1977); VARNES (1978); BELL \& PETTINGA (1988), referidos em ZÊZERE (2000), sugerem mesmo que estes testemunhos constituem uma das principais características deste tipo de deslizamentos. Por outro lado, os deslizamentos rotacionais (slump) ocorrem preferencialmente ao longo de superfícies de ruptura curvas, em meios geralmente homogéneos e isotrópicos (SIRIEYS, 1984, referido em ZÊZERE, 2000). Assim, em termos de morfodinâmica, a componente de deslizamento deverá ter apresentado um estilo de actividade simples,

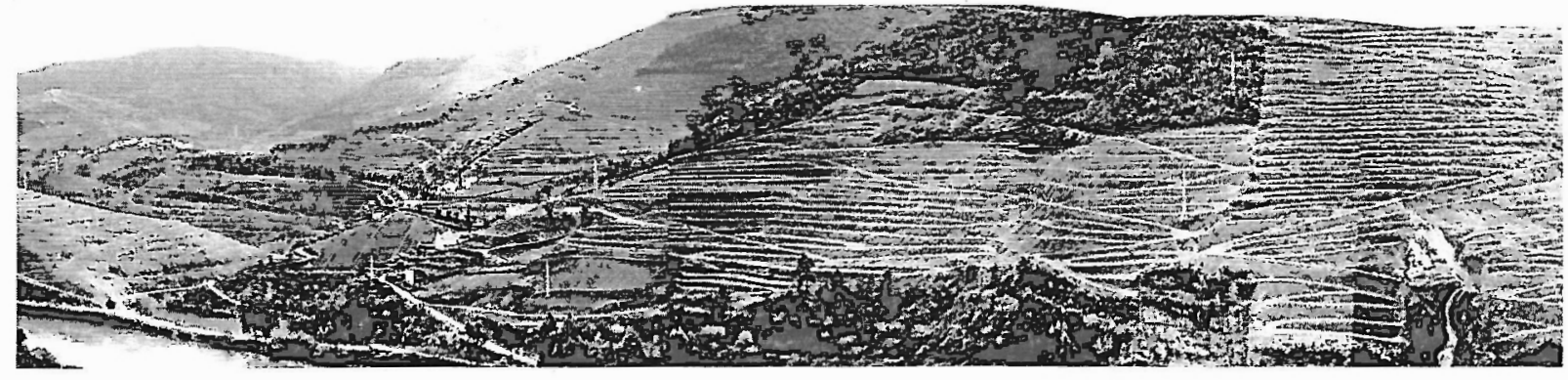

Foto 10 - A vertente onde ocorreu o movimento de Armamar, na margem sul do Douro (visto para Sul). 


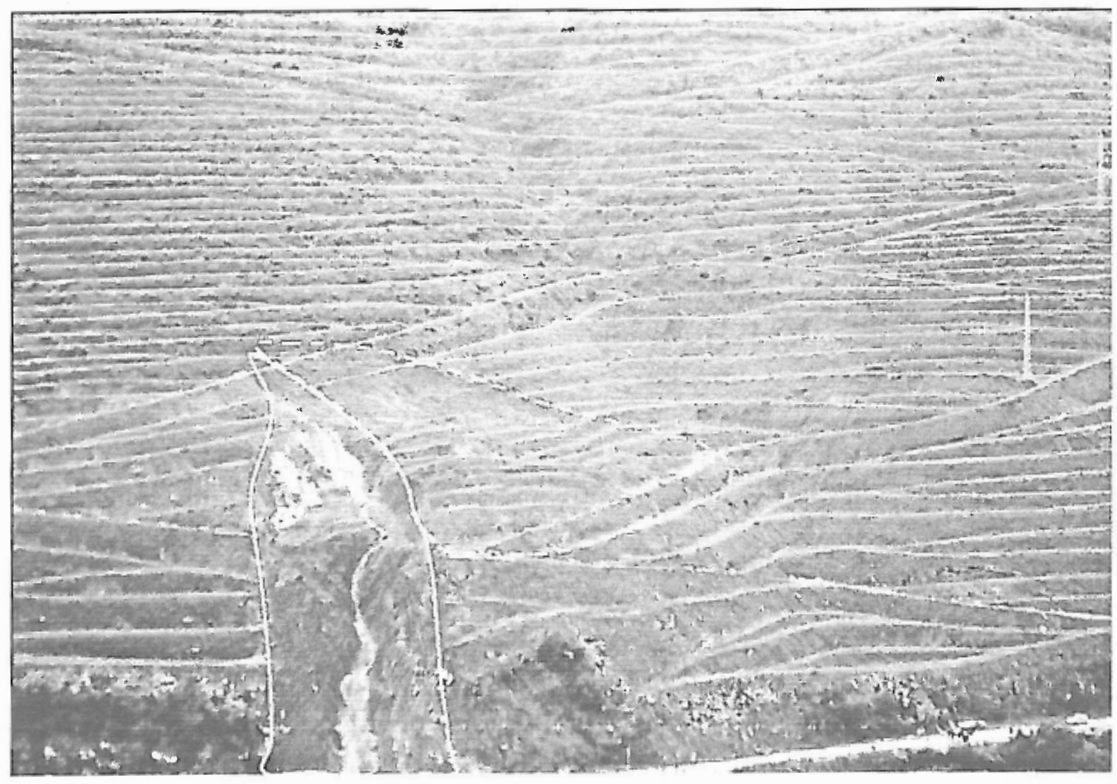

Foto 11 - Pormenor da foto 10 ; ao centro na imagem, a tracejado, a área instabilizada por um deslizamento planar de material detrítico (debris block slide)

Foto 12 - Cabeceiras do
movimento e plano de ruptura
principal do deslizamento.

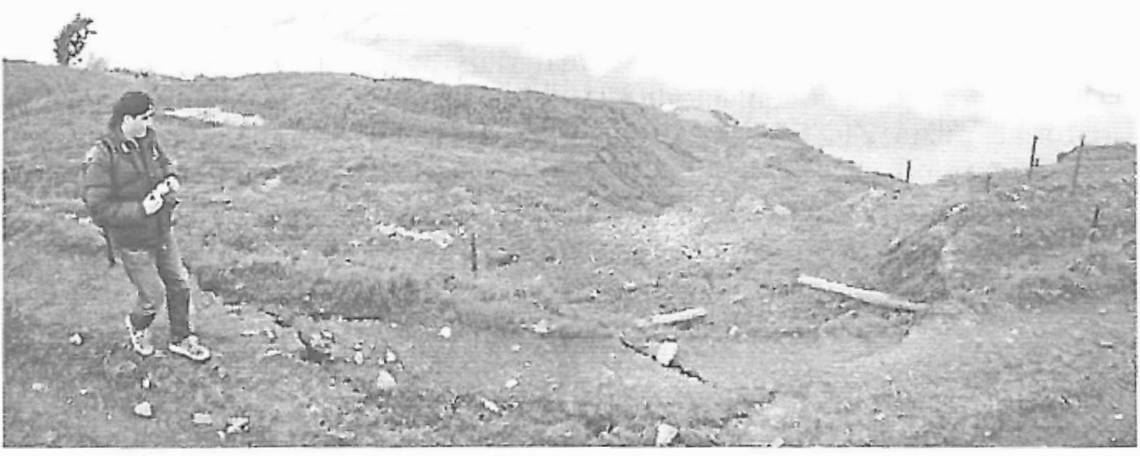

relacionado com uma única ruptura, ou pelo menos com aquela que justifica o essencial da deslocação do movimento como um bloco que posteriormente poderá ter-se fragmentado em pequenos sectores ligeiramente desencontrados. No entanto, as evidências deste facto, no terreno, assim com nas fotos apresentadas, não são muito elucidativas pelo que, desde o início, retivemos a ideia de um movimento mais ou menos contínuo, emjeito de "debris block slide" do conjunto da massa deslizada (cfr. foto 11). Depois de ter perdido apoio basal e lateral devido à movimentação da massa fluidificada este sector da vertente deverá ter-se deslocado ligeiramente. A distribuição da actividade foi progressiva, do tipo "em avanço", e a natureza do movimento associada a testemunhos das

(13) Desde a barragem do Bagaúste até à área onde ocorreu o movimento de Armamar, identificámos pelos menos mais três sectores onde houve reactivação de movimentos de menor dimensão ou onde deverão tar ocorrido outros talvez tão importantes como o movimento em estudo (fotos 13 e 14). Uns e outros sublinham a importância da estrutura, já amplamente dissecada e ajudam a compreender a expressão "país dos flow slides", introduzida no início do trabalho.
Folografia de A. Gomes, FLUP populações locais recolhidos no momento, sugerem que se trate de um processo de reactivação de um movimento antigo ${ }^{(13)}$, para o qual deverão ter concorrido diversos factores: por um lado, os factores condicionantes já referidos mas, por outro lado, as alterações introduzidas no escoamento de toda a vertente resultante das obras de recuperação de toda a morfologia de socalcos para o cultivo da vinha, que haviam sido destruídos aquando do Outono-Inverno de 20002001. Esta área, deverá ter sido instabilizada devido à concentração local de um incremento hídrico que pode encontrar justificação na ruptura de um dos canos que desviavam a drenagem de uma linha de água que, desde logo, estranhámos não ter escoamento sub-aéreo quando todas as outras pequenas linhas de água, algumas, de primeira ordem, pelas quais havíamos passado tinham caudais significativos e até quedas de água. Por outro lado o traçado rigidamente rectilíneo e o facto de a desembocadura, na margem esquerda do Douro, ter correspondência na margem direita à desembocadura de outra linha de água, também ela 


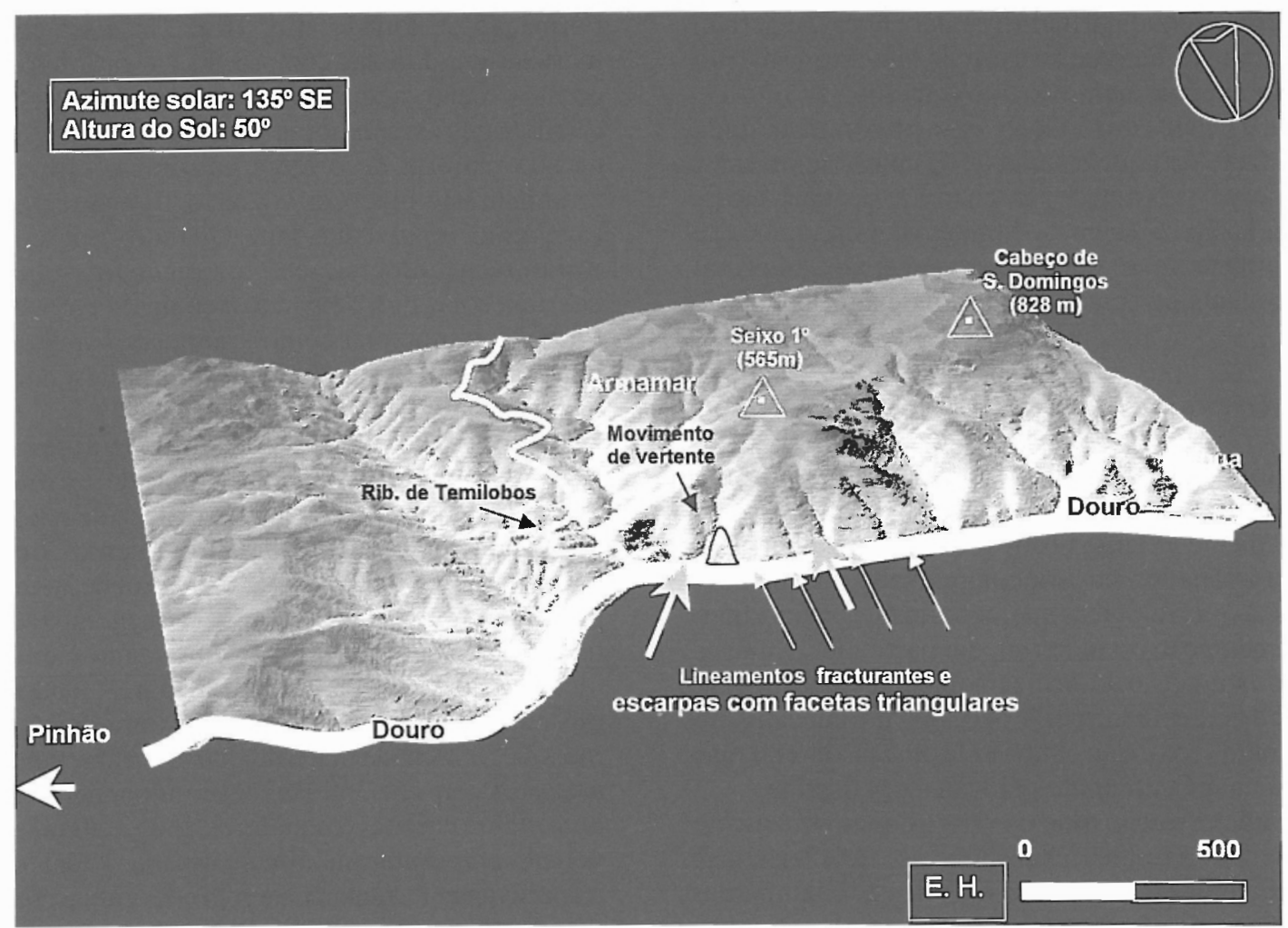

Figura 8 - Modelo digital de terreno da área em estudo, elaborado com base na altimetria original com escala 1/ 10000. (Esta informação foi gentilmente cedida pela Câmara Municipal de Armamar).

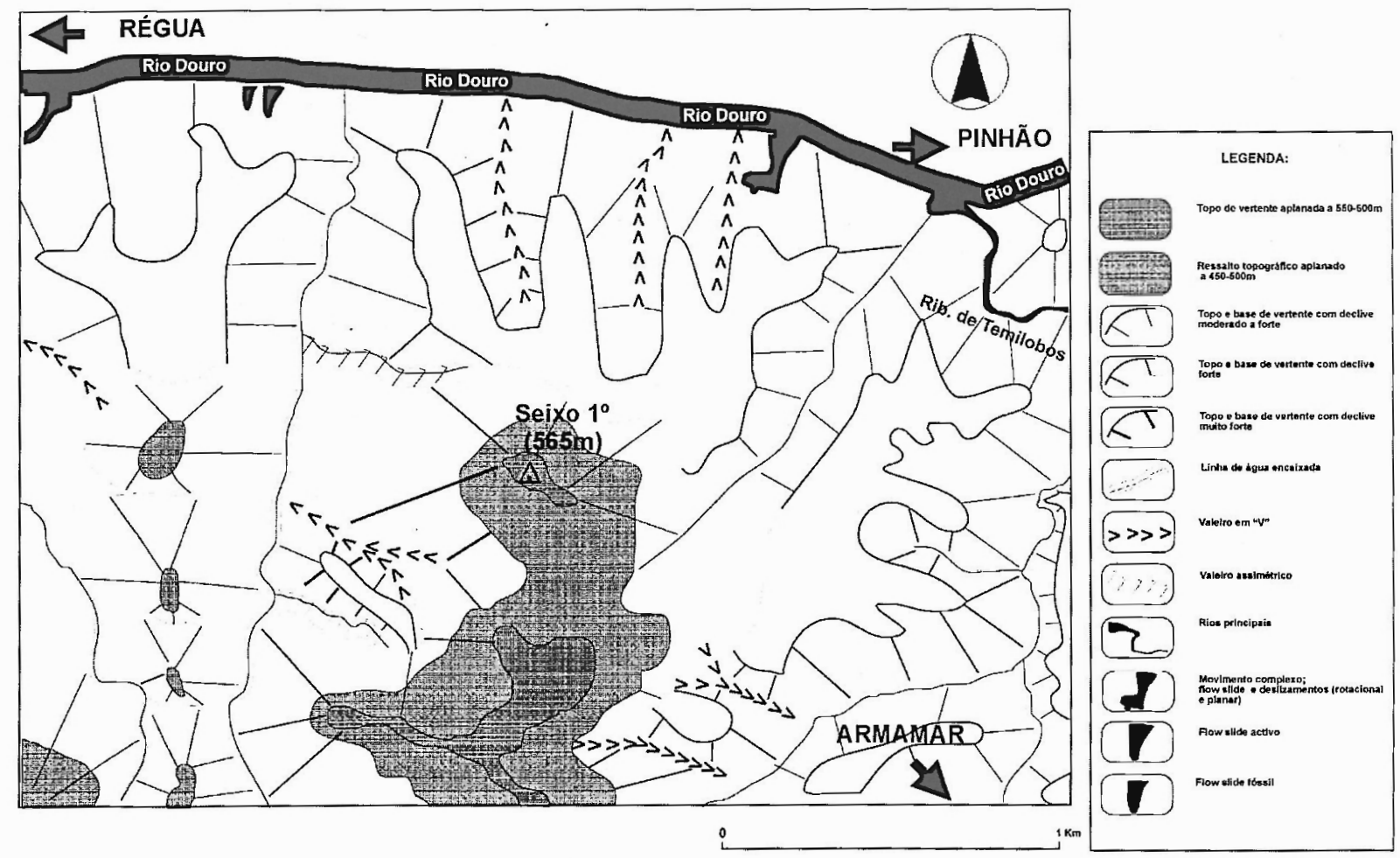

Figura 9 - Esboço morfodinâmico de pormenor da área onde ocorreu o movimento de vertente de Armamar. 
com perfil longitudinal muito regulare linear, sugeriam um contexto de adaptação a um lineamento se não do tipo falha, seguramente do tipo fractura (cfr. foto 11, figs. 8 e 9). Esta constatação fez-nos estranhar ainda mais o facto de aquela linha de água não apresentar escoamento sub-aéreo percebendo-se, mais tarde, razão pela qual o desencadeamento das condições de instabilidade teve lugar numa posição marginal relativamente ao traçado da linha de água referida.

\section{Parâmetros morfométricos}

Ao longo do caminho de terra batida que delimita as cabeceiras do movimento são visíveis fissuras relativamente extensas (cfr. foto 12), que chegam a atingir a dezena de metros de comprimento, constituindo evidências morfológicas que, certamente, anteciparam a movimentação do material, em particular, a que se deslocou sob acção do deslizamento rotacional inicial, e a que foi afectada, em bloco, por um mecanismo planar num sector que ocupa uma posição lateral mas contígua à área afectada pelo fluxo deslizante.

A caracterização morfométrica do movimento de vertente de Armamar sublinha as características morfodinâmicas propostas, mas destaca também a importância da estrutura do relevo para a localização e dimensão do movimento, em particular, o facto de se verificar uma relação de conformidade entre o declive das vertentes e a inclinação das bancadas da
Formação de Pinhão (fig. 10 e 11). Este contexto morfostrutural ajuda a compreender a feição superficial do movimento que afectou basicamente a cobertura detrítica que assenta sobre aquela Formação (fig. 11), na sua maioria de origem antrópica, utilizada no arranjo morfológico, em socalco, das vertentes utilizadas para o cultivo da vinha. Quando, neste contexto estrutural a litologia coerente se encontra sobreposta por uma cobertura detrítica, o contacto entre as duas formações funciona como "rampa newtoniana", ao longo da qual, os materiais suprajacentes, depois de instabilizados, se podem deslocar.

Os fortes declives existentes, a reduzida resistência ao corte e o carácter anisotrópico da estrutura do relevo constituem três grandes ordens de razões que justificam a ocorrência de um Movimento Complexo com enorme capacidade de destruição onde intervieram pelo menos três mecanismos sequencializados no tempo mas cujo principal foi seguramente, um mecanismo do tipo "Fluxo deslizante". Todos estes mecanismos concorreram para a movimentação de mais de $5000 \mathrm{~m}^{3}$ de material detrítico, afectando uma área com cerca de $3600 \mathrm{~m}^{2}$ definindo um movimento de vertente cujos eixos maiores, longitudinal e transversal, apresentaram dimensões de $120 \mathrm{~m}$ e $67 \mathrm{~m}$, respectivamente. Juntamente comodesviodas condições naturais da drenagem provocado pela acção antrópica, a morfodinâmica e a morfometria do movimento permitem compreender o desencadear de condições de instabilidade na vertente onde ele ocorreu, mas

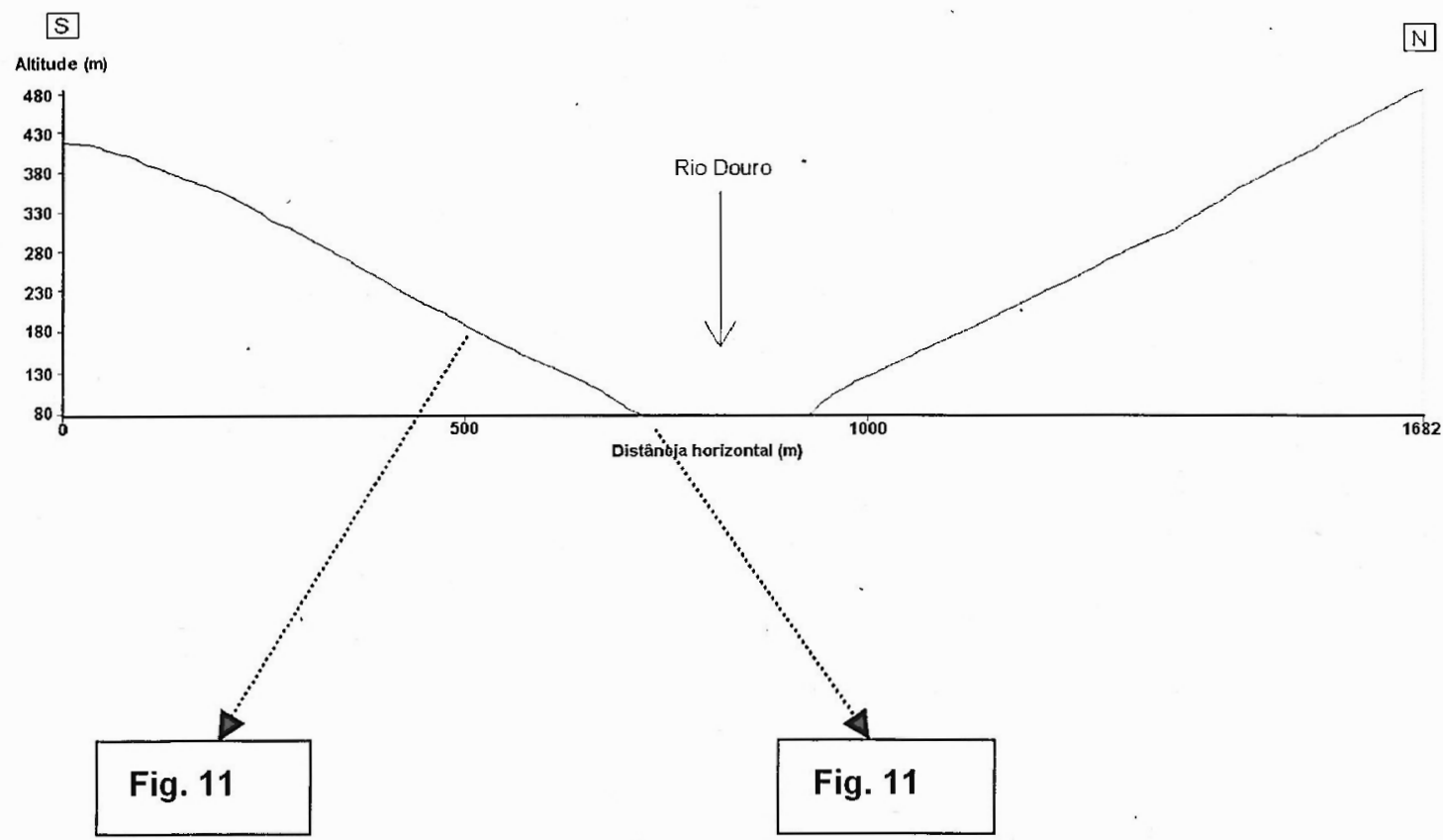

Figura 10 - Perfil topográfico transversal ao Rio Douro no sector do Movimento de Armamar (as duas setas a tracejado indicam os pontos extremos do perfil apresentado na fig. 11). Sem ampliação da escala vertical. 
SSE

Altitude $(m)$

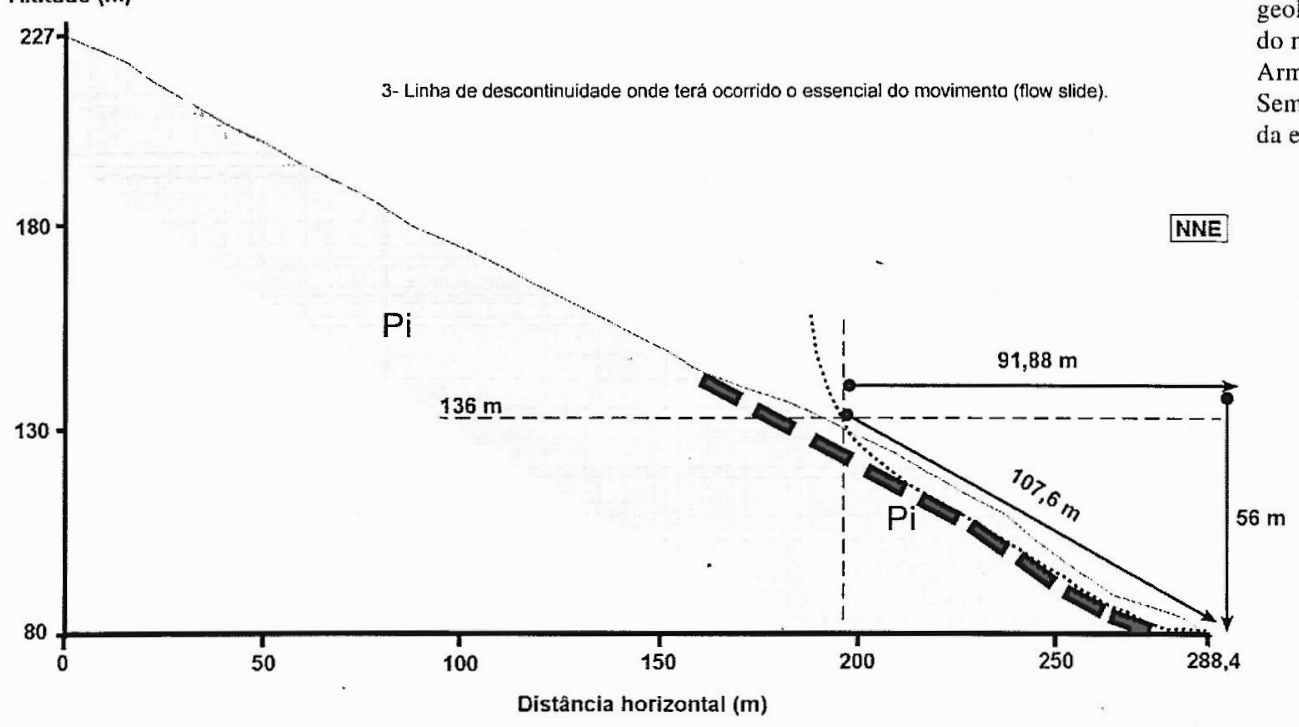

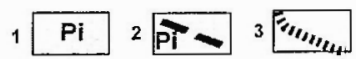

LEGENDA:

1- Formação (Filitos cloriticos, quartzo-cloriticos e metaquartzovaques); 2- idem com magnetite;

3- Linha de descontinuidade (rampa) de Fluxo/deslizamento sobre a qual se deverá ter processado a deslocaçāo do material.
Figura 11 - Perfil geológico e morfometria do movimento de Armamar.

Sem ampliação da escala vertical. permitem ainda explicar a sua estranha localização, ao lado de um contexto hidro-morfodinâmico, teoricamente, mais susceptível de instabilizar, ou seja, a linha de água que se encontrava sem drenagem sub-aérea. Na figura 12, apresentam-se os principais parâmetros morfométricos que caracterizaram o Movimento Complexo de Armamar.

\section{Significados sedimentológico e morfodinâmico do material movimentado}

Decorridas cerca de 10 horas após o acidente, a deslocação ao local permitiu-nos recolher dados qualitativos muito importantes, quer ao nível de relatos de pessoas que presenciaram de modo muito

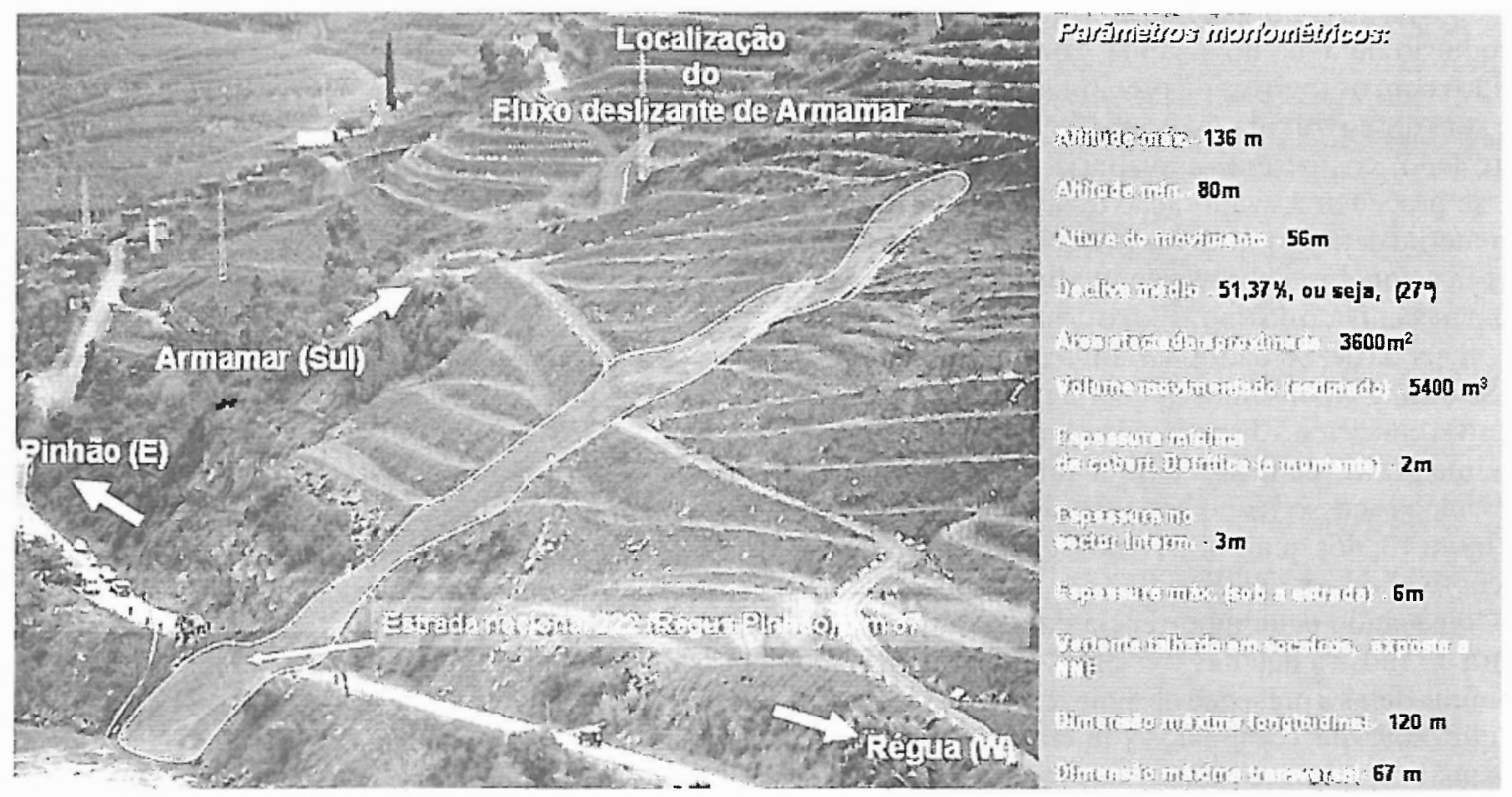

Figura 12 - O Fluxo deslizante.de Armamar; tabela-síntese de parâmetros morfométricos. 


\section{Tabela l- Relação saturação / presença em água, estimada para as três amostrascolhidas}

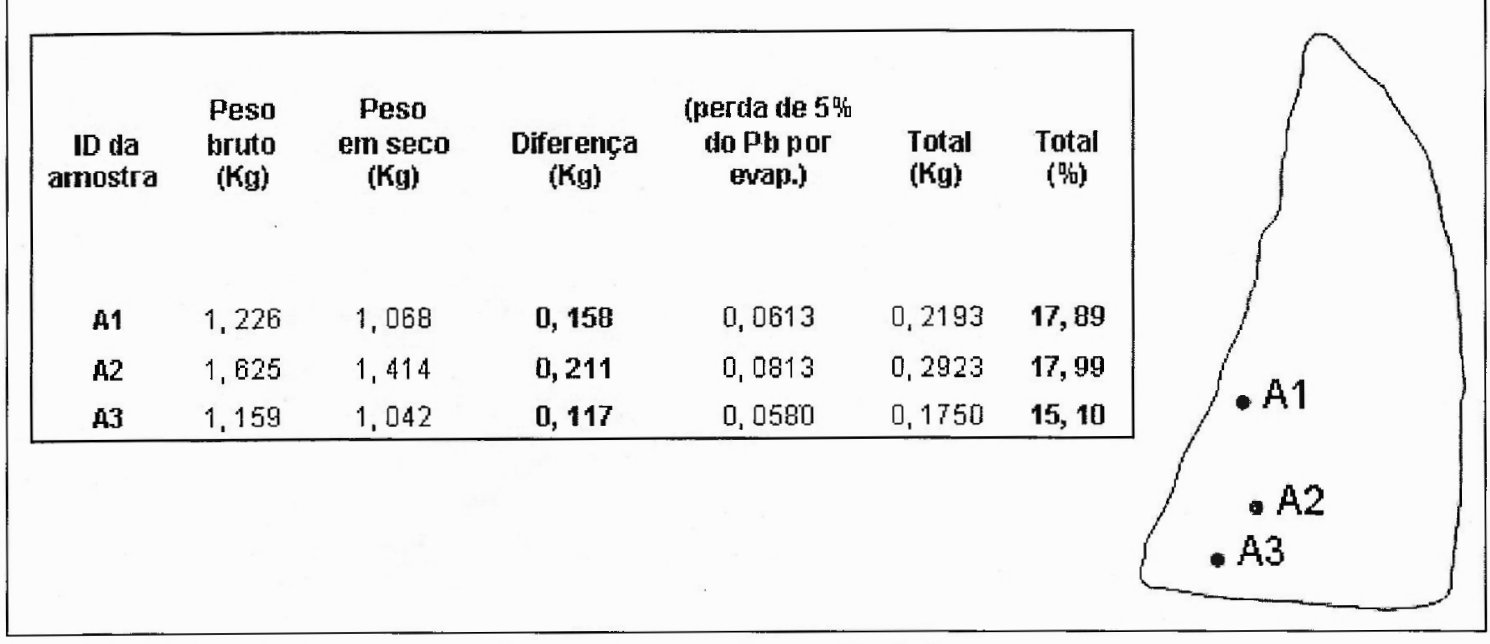

Figura 13 - Localização dos sectores onde se recolheu material para análise (à direita) e tabela-síntese dos resultados obtidos.

próximo a ocorrência, quer ao nível da recolha de material para análise laboratorial. Queremos, no entanto, destacar que mais do que avaliar a importância do teor e tipo de minerais argilosos em presença, tentámos apenas perceber a influência que o comportamento geomecânico desses mesmos minerais poderia representar para o desencadeamento de condições de instabilidade na vertente e na própria velocidade de movimentação do conjunto detrítico. Salientamos, também, que o objectivo fundamental da recolha de material para amostragem centrou-se fundamentalmente na possibilidade de aferir a importância da introdução de água no sistema, comparar os dados obtidos com os registos da precipitação (informação que será desenvolvida mais adiante) tarefa que, por outro lado, nos permitira avaliar a velocidade com que se procedeu à evaporação da água no conjunto do material detrítico. Esta razão de evaporação levar-nos-ia a concluir sobre a eventualidade de se tratar de um mecanismo do tipo "Fluxo deslizante" hipótese que, mais tarde, os dados viriam a confirmar.

Se de início pensámos que seria possível recolher amostras emsectores distintos do material movimentado movimento, a realidade viria a impor que apenas tivéssemos acesso físico aos sectores representados na figura 13 , dos quais obtivemos, de facto, material susceptível de ser analisado.

Começando pela importância do teor em água, a figura 13 mostra que nas três áreas amostradas, em nenhuma delas a presença de água representava mais do que $20 \%$ da composição inicialmente tomada para análise, o que revela uma grande densidade da carga sólida. No que diz respeito à fracção argilosa, nas primeira e segunda amostras obtivemos um valor de $30 \%$ do peso inicial ${ }^{(14)}$; já para a terceira amostra, o valor obtido $-27 \%$ - foi ligeiramente inferior ao das duas amostras recolhidas em sectores mais a montante, situação que não estranhamos devido ao facto de esta amostra conter já parte do material, mais grosseiro, utilizado no enchimento do aterro da estrada. Estes dados poderão significar que o tipo de cobertura detrítica em presença deveria apresentar uma textura francamente porosa na medida em que a fracção grosseira representa cerca de $50 \%$ do peso total nas três situações amostradas, porventura menos argilosa do que se esperava, uma vez que nesta área o material de cobertura que estrutura os socalcos é, geralmente, mais fino.

O recurso à difracção por RX evidenciou a presença de inter-estratificados dotipo 7-10-14 $\AA$, concretamente, uma associação Vermiculite/Clorite + Ilite + Caulinite, com leve predomínio da primeira na amostra localizada mais a montante e com predomínio de Ilite nas duas restantes amostras. Em todos os casos, a clorite parece, no entanto, estar presente em quantidades muito significativas o que pode significar que, não sendo um produto secundário resultante de evolução diagenética, poderia estar directamente relacionada com a alteração de rochas magmáticas ou metamórficas, predominantes nesta área; no entanto, a sua localização preferencial sobre afloramentos metassedimentares pode deixar adivinhar outras alternativas para a sua proveniência dado que estes minerais poderiam ser para ali transportados por acção antrópica ou, ainda,

(14) Foram contabilizados os valores após a perda de material durante o processo de análise. 
poderiam ter origem nas cabeceiras graníticas, não muito distantes, das linhas de água que drenam esta área da bacia do Douro. Em qualquer dos casos, independentemente da constituição mineralógica da fracção argilosa, parece legítimo concluir que, não sendo desprezível, a percentagem de argila existente nas três amostras é muito inferior ao valor da fracção silto-arenosa. Admitimos, por isso, que a forte porosidade doconjunto facilmente conduziria a água introduzida localmente no sistema-vertente, em débito continuado e prolongado por várias horas, até ao plano de descontinuidade localizado no contacto com a rocha coerente, a pouca profundidade, com a consequente instabilização do conjunto detrítico. Estes dados poderão ter algum reforço se pensarmos que os valores da precipitação (efeito intensidade e acumulação) estavam ainda enquadrados nos valores normais embora se aproximassem já dos limiares críticos propostos em trabalhos anteriores para a área em questão (J. G. SANTOS, 2002). Tal facto poderia significar que a localização do movimento ficaria a dever-se, talvez mais, a um mecanismo antrópico responsável pelo carácter anómalo da injecção hídrica localizada, estranha ao normal funcionamento hidrodinâmico do sistema-vertente, apontando-se como argumento provável para esta hipótese, a ruptura de um dos drenos através dos quais se havia procurado retirar benefícios individuais para a estrutura dos socalcos. Em nosso entender, deverá ter sido este o factor responsável pela instabilização de todo o conjunto, devido ao excesso de água localizado neste sector da vertente, já que a precipitação, por si só, não chega, sobretudo, para explicar a localização do movimento.

\section{Factores desencadeantes - quadro meteoro- lógico-climático e actividade antrópica}

Apesar de importante, o quadro meteorológicoclimático parece não ter evidenciado condições muito próximas dos limiares críticos propostos em trabalhos anteriores ((J. G. SANTOS, 2002). Os dados da precipitação disponibilizados pela Estação de Avisos do Douro (EAD), localizada a $70 \mathrm{~m}$, revelaram que entre 1 de Janeiro de 1990 e 1 de Janeiro de 2001 o valor médio anual registado foi de $851,2 \mathrm{~mm}$. De acordo com os dados agora disponíveis, para um intervalo de tempo de 32 anos (compreendido entre o dia 1 de Janeiro de 1971 e o dia 31 de Dezembro de 2002 ), aquele valor sobe ligeiramente para 862,8 $\mathrm{mm}$, o que nos permite concluir que os dados relativos ao período de 11 anos com os quais desenvolvemos um estudo de pormenor sobre os movimentos de vertente de Ariz e de Alvações do Corgo, não se afastam, de modo significativo, dos valores actualizados para um intervalo de tempo significativamente mais longo.

Tal como procedemos no trabalho anteriormente referido, depois de determinado o valor de precipitação acumulada nos quatro meses que antecederam o movimento-714,6 mm (figs. 14 e 15) - verificou-se que este indicador está significativamente aquém do limiar de crise proposto, ou seja, do valor da precipitação média anual para qualquer um dos dois períodos considerados. Assim, numa primeira abordagem, a proposta de definição de um momento crítico sempre que a precipitação acumulada (em quatro meses) se aproximasse do total médio anual, após a existência de um período seco de, pelo menos, 45 dias com valores diários de precipitação inferiores a $5 \mathrm{~mm}$ (MÉNEROUD, 1983), aparentemente, nãose confirma, tal como foi proposto em estudos anteriores. No entanto, nesses mesmos estudos recorremos a um postulado que propunha que estas condições deveriam verificar-se com forte probabilidade entre o "... final do mês de Dezembro e o final do mês de Janeiro, o que parece ter tido confirmação pela data de ocorrência do movimento de vertente em questão (recorde-se, dia 2 de Janeiro de 2003). Por outro lado, na mesma obra havíamos admitido também a possibilidade de atingir o limiar crítico numa altura do ano fora da baliza cronológica proposta, em função de condicionalismos locais e/ou sob acção de precipitação anormalmente intensa registada numa curta série de dias anormalmente pluviosos, o que parece também não ter ocorrido (figura 16).

Deste modo, apenas conseguimos compreender o contexto da ocorrência do movimento de vertente de Armamar, no espaço e no tempo, se recorrermos a factores alheios aos condicionalismos dos sistemas vertente, factores necessariamente relacionados com a actividade antrópica. Pensamos, assim, que a acção de um pequeno deslizamento rotacional ou de um simples desabamento de terras deverá ter conduzido à ruptura de um cano que pretendia desviar drenagem natural das águas de um pequeno ribeiro relativamente ao qual havíamos já manifestado alguma estranheza perante o facto de não ter escoamento sub-aéreo. Esta situaçãodeverá ter sido responsável pela introdução de uma quantidade significativa de água neste sector da vertente, podendo mesmo ter conduzido à saturação da cobertura detrítica ou, apenas, ter atingido a superfície de descontinuidade estabelecida entre o material solto e a rocha coerente induzindo uma dinâmica de "rampa de movimentação" de detritos aolongo da vertente. Ficam, no entanto, por esclarecer questões relacionadas, por um lado, com a quantidade de água que terá sido introduzida localmente no sector onde ocorreu o movimento e, por outro lado, com o tempo que deverá ter decorrido entre a referida ruptura e a ocorrência do movimento. 

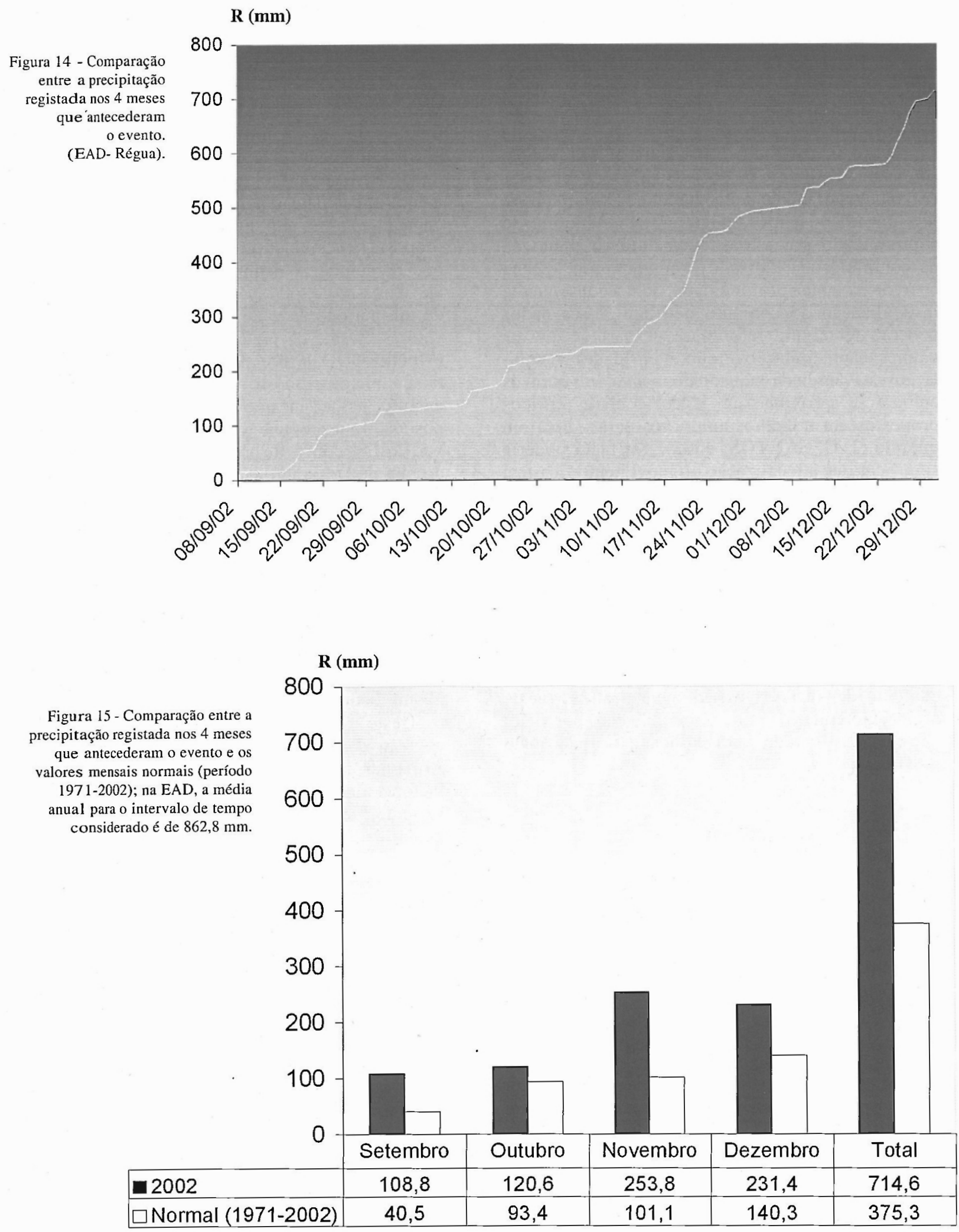


\begin{tabular}{|c|c|}
\hline Data & $\mathrm{R}(\mathrm{mm})$ \\
$23-12-02$ & 3,6 \\
$24-12-02$ & 13,2 \\
$25-12-02$ & 27,3 \\
$26-12-02$ & 24,1 \\
$27-12-02$ & 31,6 \\
$28-12-02$ & 19,3 \\
$29-12-02$ & 0,0 \\
$30-12-02$ & 5,7 \\
$31-12-02$ & 14,2 \\
Total & 139,0 \\
\hline
\end{tabular}

* Não dispúnhamos de dadios relativos de Janeiro de 2003 mas sabemos que ate ao dia 5 haviam sido registados $74,6 \mathrm{~mm}$.

Tabela II - Episódio pluvioso (9 dias)*

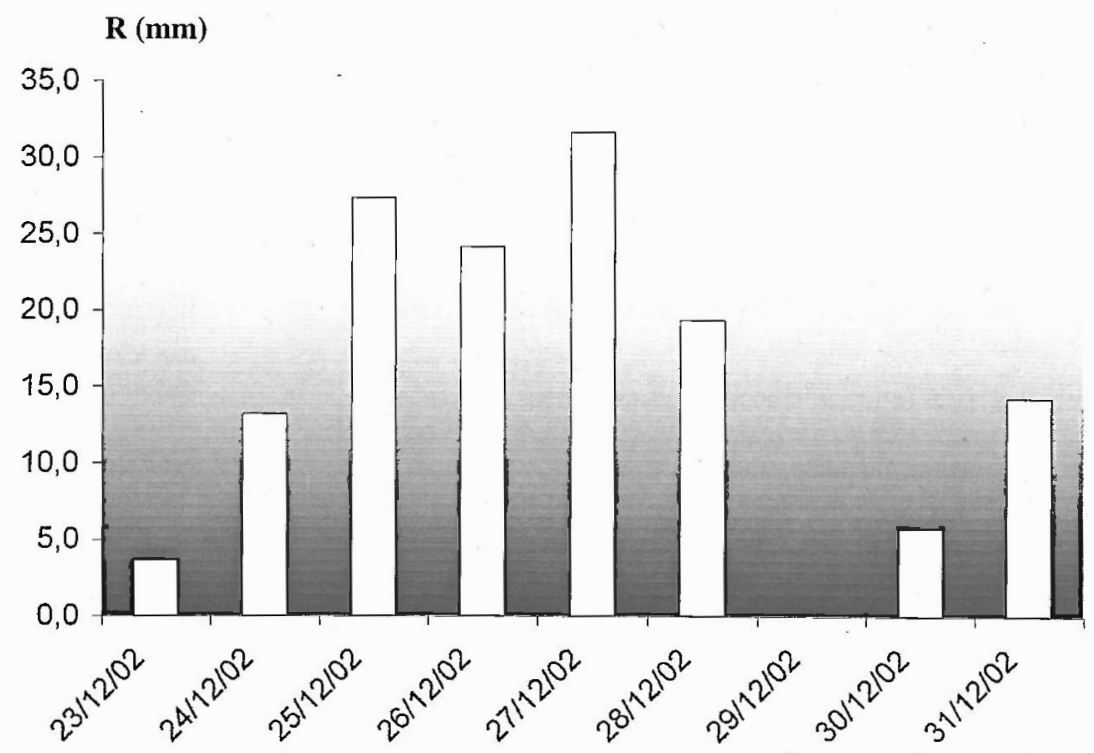

Figura 16 - Precipitação ocorrida durante o episódio pluvioso que antecedeu o evento*
Em síntese, só o cruzamento dos diversos tipos de dados relativos aos "factores condicionantes" $\mathrm{e}$ aos "factores desencadeantes", pode ajudara compreender o momento e sobretudo, a localização do movimento de vertente de Armamar. Pensamos, contudo, que a actividade antrópica, seja por imprudência, simples desconhecimento, ou pura conveniência pessoal, deverá ter assumido um papel nuclear no desencadear de condições deinstabilidade nosistema vertente, situação que resultou de condutas negligentes que poderiam ter conduzido a um desastre com contornos bem diferentes, que nos poderiam fazer recordar outras catástrofes recentemente ocorridas, ali bem próximo, imediatamente a jusante da confluência dos rios Douro e Tâmega.

\section{Conclusão}

Quando aplicada aos movimentos de vertente, a Análise do Risco deve ser fundamentada em modelos mistos, com dados quantitativos e qualitativos que permitam contemplarum leque tão diversificado quanto possível de combinações entre as diversas variáveis, potencial ou factualmente envolvidas. Salientamos que se torna urgente distinguir dois contextos com motivações opostas, mas complementares: um contexto factual que implica umestudo com carácter retrospectivo, e um contexto potencial, com carácter prospectivo onde a cartografia desempenha um papel determinante, mas que não pode ser posto em prática sem recorrer a uma base de dados, normalmente disponibilizada pelo primeiro dos contextos referidos. Em jeito de remate conclusivo, os movimentos de vertente são, de facto, uma das maiores ameaças à segurança das populações do Douro Vinhateiro, ameaça que vem crescendo ao ritmo do próprio crescimento acelerado das vulnerabilidades e dos elementos em risco.

\section{Agradecimentos}

Não podemos deixar de destacar, ainda que em breve nota, o contributo importante da Comissão de Coordenação da Região Norte (CCRN) na pessoa do Sr. Eng. Figueiredo Pereira que nos atendeu com elevada distinção sempre que a necessidade de mais informação, quase sempre fornecida em suporte digital, nos conduzia inevitavelmente ao seu contacto. Ao Centro Nacional de Informação Geográfica (CNIG) agradecemos a informação orto-fotogramétrica e ao IGeoE, a cartografia de base disponibilizada em formato vectorial, documentos importantes para a prossecução dos objectivos do trabalho. À Estação de Avisos do Douro, na pessoa do Eng. José Freitas, agradecemos a disponibilização, em tempo útil, dos dados relativos à precipitação. A presente investigação não poderia ser posta em marcha sem o importante contributo da Câmara Municipal de Armamar que amavelmente nos facultou informação cartográfica de pormenor em suporte digital. É, ainda, com reconhecida gratidão que referimos também a importância do apoio que nos tem sido dado, desde há já alguns anos, pela Câmara Municipal de Vila Flor a quem, na pessoa do seu Presidente, o Dr. Artur Pimentel, agradecemos o indispensável apoio logístico. 


\section{Referências bibliográficas:}

BRUM FERREIRA (1978) - Planaltos e Montanhas do Norte da Beira. Estudo de Geomorfologia. Lisboa, CEG.

BRUNSDEN \& PRIOR (1984) - Slope Instability. New York, John Wiley \& Sons, $603 \mathrm{p}$.

CARCEDO AYALA, F. J. (1991) - Manual de Ingenieria de taludes. Intituto Teconológico Geominero de España (ITGE), Madrid, $455 \mathrm{p}$.

CRUDEN, D. \& FELL, R. (1997) - "Landslide Risk Assessment". Proceedings of the International Workshop on Landslide Risk Assessment, Honolulu, Balkema, Roterdão.

DIKAU, ET AL. (1996) - Landslide Recognition; Identification, Movement and Causes. John Wiley \& Sons, Chichester, 251p.

GARLAND, G. \& OLIVIER, M. (1993) - "Predicting landslides from rainfall in a humid, sub-tropical region". Geomorphology, 8, p.165-173.

JULIVERT, M., FONTBOTÉ, J. M., RIBEIRO, A. \& CONDE, L. (1974) - Memoria explicativa del Mapa tectónico de la Península Ibérica y Baleares. Madrid.

MÉNEROUD, J. P., (1983) - "Rélations entre la pluviosité et le déclenchement de mouvements de terrain ". Bull. Liaison Lab. Pet. Ch, 124, p. 89-100.

REBELO, F. (1995) - "Os conceitos de Risco, Perigo e Crise e a sua aplicação ao éstudo dos grandes incêndios florestais". Biblos, Coimbra, LXXI, p. 510-527.

SANTOS, J. G. (2002a)- "Movimentos de vertente na área de Peso da Régua; análise e avaliação multicritério para o zonamento de hazards em ambiente SIG ". Territorium, MinervaCoimbra, 9, p. 53-73.

SANTOS, J. G. (2002b)- "Cartografia automática do risco de movimentos de vertente; estudo aplicado à área de Peso da Régua, Bacia do Douro (Norte de Portugal) “. Xeográfica, Santiago de Compostela, 2, p. 33-57.
SANTOS, J. G., BATEIRA, C., TELES, V. \& FERREIRA, R., (2003) - Susceptibilidade a movimentos de vertente. Diagnóstico e caracterização de sectores-problema na área centro-ocidental do Norte de Portugal. Relatório de teor geográfico aplicado ao Ordenamento do Território. Coimbra, IEG-CEG, DRAOT-Norte, 122 p.

SANTOS, J. G., CUNHA, L. \& FERREIRA, R. - "Environmental marginality and natural disasters; a case study at Régua (Portugal) in the Douro wine region". Dynamics of Marginal and Critical Regions. International Geographical Union, Ashgate, Aldershot, United Kingdom, (em publicação).

SILVA, A. F. \& RIBEIRO, A. (1985) - "Thrust tectonics of Sardic Age in the Alto Douro Region (North eastern Portugal) ". Comunicações Serv. Geol. Portugal, 71 (2), 151-157.

SOUSA, B. \& SEQUEIRA, A. (1989)-Noticia Explicativa, Folha 10-D (Alijó), Carta Geológica de Portugal na escala 1/50 000. Lisboa, Serviços Geológicos de Portugal, 83 p.

SOUSA, M. B. (1982) - Litostratigrafia e Estrutura do "Complexo Xisto-Grauváquico ante-Ordovicico" - Grupo do Douro (Nordeste de Portugal). Dissertação de Doutoramento, Mus. Lab. Min. Geol. Univ. Coimbra, Coimbra, 223 p.

VARNES, D. J. (1984) - "Landslide hazard zonation: a review of principles and practice". Natural Hazards, Vol. 3. Paris, UNESCO, 63 p.

VARNES, D. J. (1978) - "Slope movements; types and processes". Landslides: analysis and control. Transportation Research Board, National Academy Sciences, Washington, Report 176, Chapter 2.

WORKINGPARTYONWORLDLANDSLIDEINVENTORY(1993) - Multilingual landslide glossary. International Geotechnical Societies, Canadian Geotechnical Society, Richmond.

ZÊZERE, J. L. (2000) - "A classificação dos movimentos de vertente, tipologia, actividade e morfologia". Apontamentos de Gengrafia, série: Investigação, 29 p. 